\title{
Open Roads: John D. Whiting, Diary in Photos, 1934-1939
}

\author{
Rachel Lev
}

\begin{abstract}
Over centuries, Western artists and media have created a potent visual archive of the Middle East that is largely made up of clichés of violence, chaos, and Orientalist tropes of exoticism. Contemporary photographers and cultural workers are crafting new mechanisms for memorialising history through photography as they and their fellow citizens experience it, effectively creating an archive where they belong. ${ }^{1}$
\end{abstract}

Setin 193os Palestine, Lebanon, Syria, Jordan, Egypt and Turkey,John D. Whiting's Diary in Photos series (1934-1939) offers a rare example of a visual genre intertwined with major events, daily life, family relations and personal emotive observations, sketching a rich ethnographic portrait of private and public life in Mandate Palestine and neighbouring cultures during the 1930s. In its entirety, this corpus offers the reader a rare cultural panorama of the region in the period before 1948 .

The underlying assumption of this work is the existence of a reciprocal relationship between the photographer and the photographic subject and between the photographer and the landscape. By looking at the corpus in its entirety, rather than extracting sections dealing with discrete narratives, we encounter a cartographic rendering of people, places and events Whiting encountered during his trips and exploration of the Middle East and his life as a member of the American Colony in Jerusalem. We can begin to understand the complex position that Whiting held, despite the sometimes critical interpretations that contemporary readings bring to the archive.

1 Michelle L. Woodward, "Creating Memory and History," Photographies 2, no. 1 (2009): 21-35.1 o.1080/1754076o80269693o. 


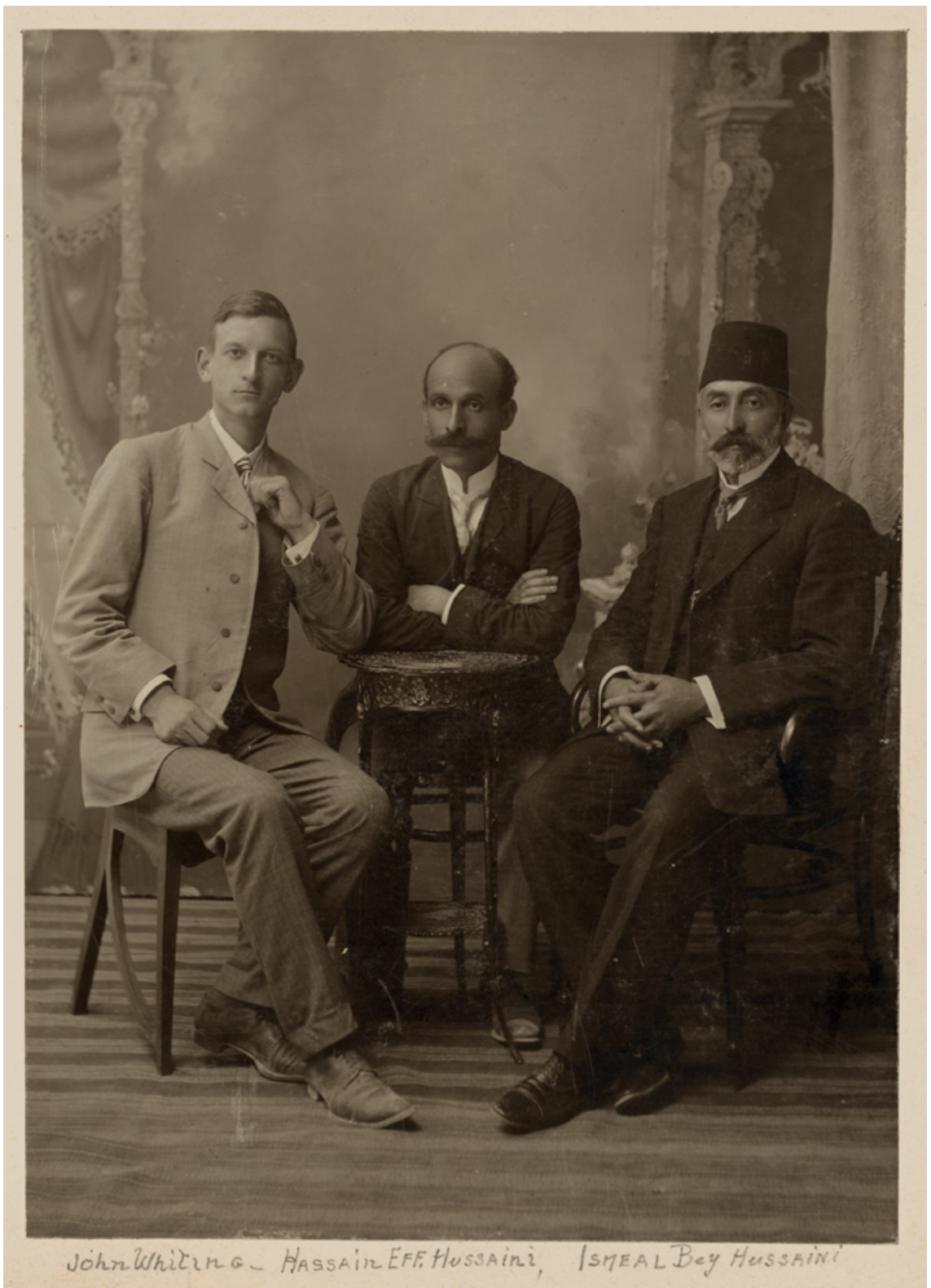

FIGURE 7.1 John D. Whiting [left], Husayn Salìm Afandīal-Husaynī (Hussein Selim Effendi al-Husseini) [Mayor of Jerusalem] and Ismā'ill Bay al-Husaynī (Ismail Bey al-Husseini) [Director of Education], c. 1908. From Members and Activities of the American Colony, c. 189o-19o6. Photograph album. Photographer Unknown. Visual Materials from the papers of John D. Whiting PRINTS \& PHOTOGRAPHS DIVISION, LIBRARY OF CONGRESS, WASHINGTON, D.C. 
Can we relate to the Diary in Photos as an autonomous corpus, in which the creator documented the Middle East in a manner that reflects the multiple identities of the subjects depicted against a constantly changing backdrop? Did his ethnographic knowledge, personality, biography and status within the American Colony in Jerusalem influence his attitude toward the various individuals, communities and places with which he interacted? Is this influence expressed across the body of the work or in specific series? Are we, as interpreters, able to read the Diary in Photos in its entirety?

John D. Whiting (1882-1951) a man of broad talents and interests, was a Jerusalem-born and a member of the American Colony in Jerusalem, an American Christian community established in Jerusalem in 1881 by small group of Americans from Chicago, Ill. Whiting worked as a personal tour guide, curator, collector, ethnographer, geographer, writer, photographer, amateur botanist and Deputy Consul of United States of America in Jerusalem. While creating the Diary in Photos, Whiting crossed Palestine and the Middle East hundreds of times, met with dozens of people, dined with kings, guided archaeological expeditions and slept in Bedouin tents. He toured capital cities and isolated settlements, teeming markets and sacred sites. He researched local cultures and published articles on natural science and ethnography in National Geographic. ${ }^{2}$ He also served as a consultant for British Mandate officials in Palestine since 1917 and participated in the British Mandate's social and political processes, as a professional, with his family and the American Colony collective.

The Diary in Photos series consists of five parchment-bound volumes $24 \mathrm{~cm}$ in height and $15 \mathrm{~cm}$ in width, each with between 100 and 250 photographs, in $9 \times 9 \mathrm{~cm}$ sepia tone prints. The photographs are mounted on cardboard, with two photographs arranged vertically on each page and four photographs per double spread. In all, the diaries consist of over goo photographs that Whiting had selected out of some 2,80o images taken with his personal Rolleiflex camera from 1934 to 1939 .

This period is particularly poignant, coinciding with both 'The Great Revolt' (by Palestinians against the British, in protest against continued Zionist immigration, 1936-39) and the Fifth Aliyah (the fifth wave of Zionist immigration from Europe, 1929-1939).

Exploration of the Holy Land as an aspect of faith was etched into the identity of the American Colony in Jerusalem from its founding by Horatio and Anna Spafford in 1881. Travel and studies of the Holy Land continued to mark

2 John D. Whiting's articles were published in National Geographic between 1913 and 1940. See the full list at the end of the bibliography. 


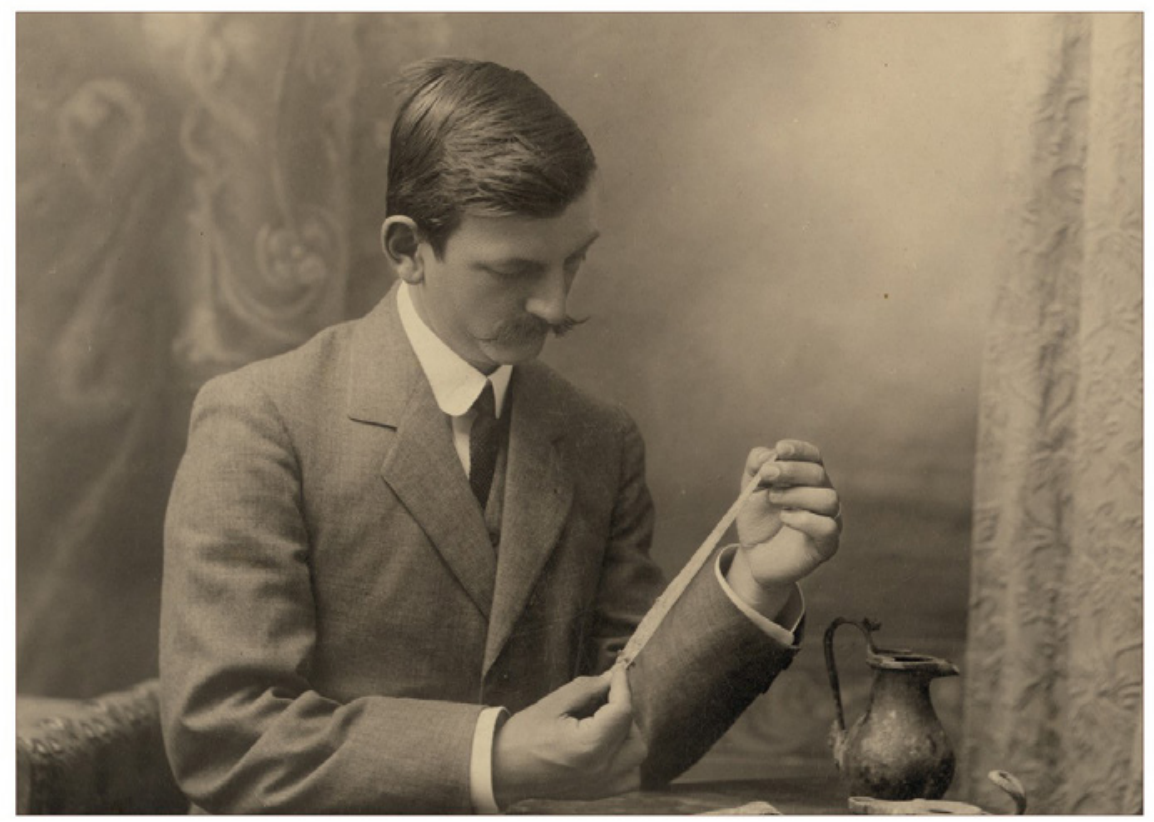

FIg URE 7.2 Studio Portrait of John D. Whiting, c. 1905-1910. From Portraits of the Vester and Whiting Families and the American Colony, 1905-1913. Photograph album. Photographer unknown. Visual Materials from the Papers of John D. Whiting PRINTS \& PHOTOGRAPHS DIVISION, LIBRARY OF CONGRESS, WASHINGTON, D.C.

the congregation's identity as younger members adopted exploration-related professions, which included archaeology, land surveying, tour guiding, photography, botany, ethnography, and hosting. The latter - hosting - exposed them to like-minded explorers and artists who would often stay for prolonged periods as their guests. Similarly, the work of the American Colony Photo Department (ACPD), a collective of fifteen known photographers of Palestinian, American, Indian and Swedish origins, involved extensive travels to remote places in well-planned photographic expeditions. ${ }^{3}$

The late nineteenth century saw the establishment of state-sponsored religious research institutes in Jerusalem, whose new inhabitants' knowledge and aspirations complemented those of the Colony. To name just a few, the French

3 Rachel Lev, "Photography and Genius Loci: Hol Lars (Lewis) Larson's photograph 'Kaiserin Augusta Victoria Stiftung on Olivet' (1910-1914)." In Tracing the Jerusalem Code, Volume III, ed. Ragnhild J. Zorgati, Anna Bohlin, 2021. 


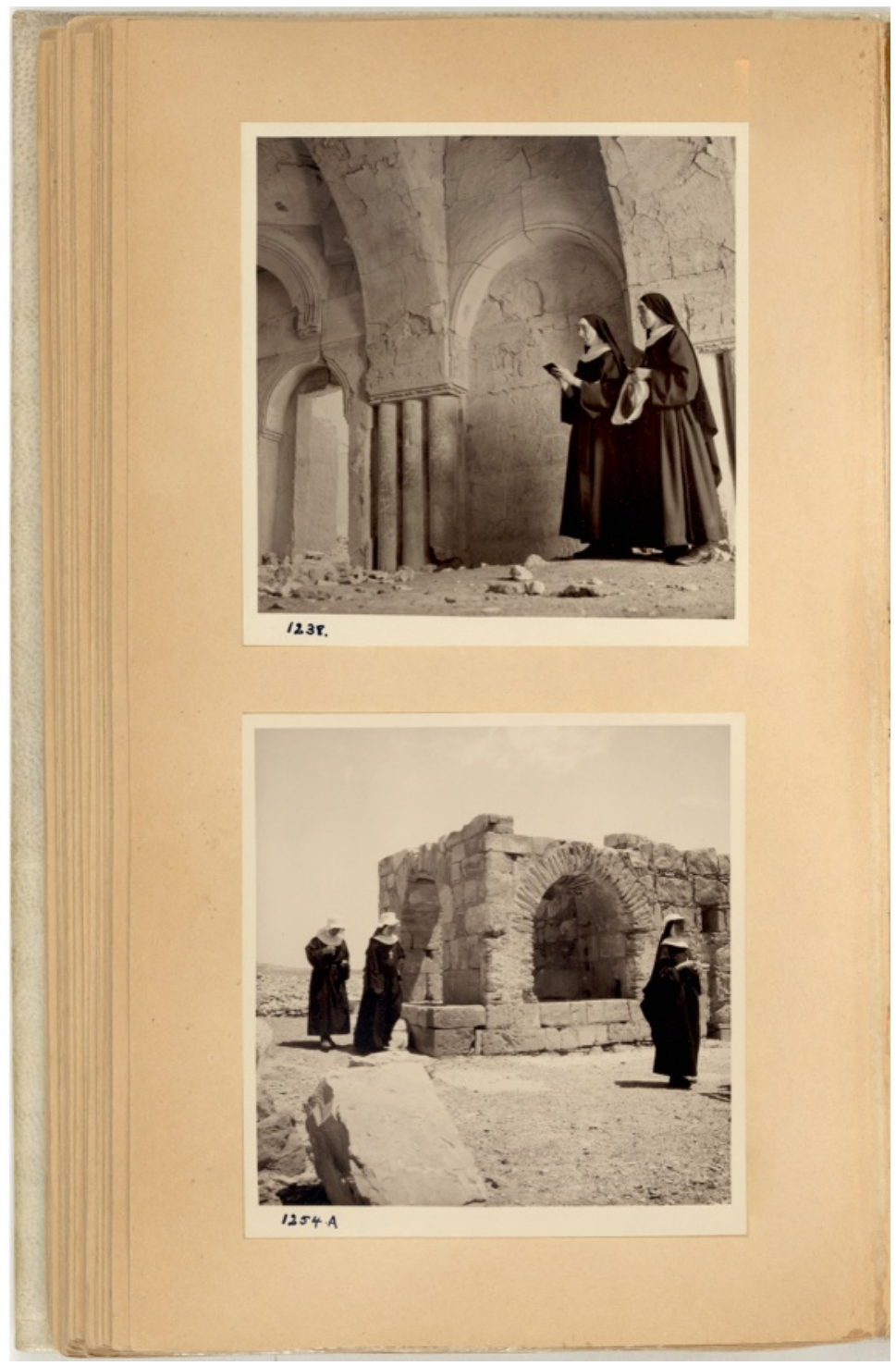

FIgURE 7.3 Typical Diary in Photos album page.

Above: Trip to Trans-Jordan with four Anglo-Catholic Sisters, 1937. Sketching in Kasr Kharani

Below: Trip to Trans-Jordan with four Anglo-Catholic Sisters, 1937. Sketching in Kasr Kharani

Note: In most cases, the Diary in Photos image captions presented here are quotations of captions written by Whiting as a supplement to his Diary.

From Diary in Photos, Volume II, 1936-1937.

Visual Materials from the Papers of John D. Whiting

PRINTS AND PHOTOGRAPHS DIVISION, LIBRARY OF CONGRESS, WASHINGTON, D.C. 
École Biblique et Archéologique Française, founded in 189o, followed by the American School of Oriental Research (today the W.F. Albright Institute of Archaeological Research), founded in 1900, and the Deutsches Evangelisches Institut für Altertumswissenschaft des Heiligen Lands, founded in 1902. The new inhabitants of these institutions established close ties with members of the American Colony that harboured similar interests. These encounters proved formative and led guests and hosts into fruitful exchanges and common ventures. For Whiting, and other younger generations of the Colony, it was a further schooling. Lars E. Lind recalls in his memoir:

Archaeology seemed to spur on the study of theology. A majority of the annual students from the colleges of Europe were theological graduates; Palestine Archaeology was in fact inseparable from Bible research. The Colony was a host to the great majority of American students and the young men of the Colony, thanks to their intimate knowledge of

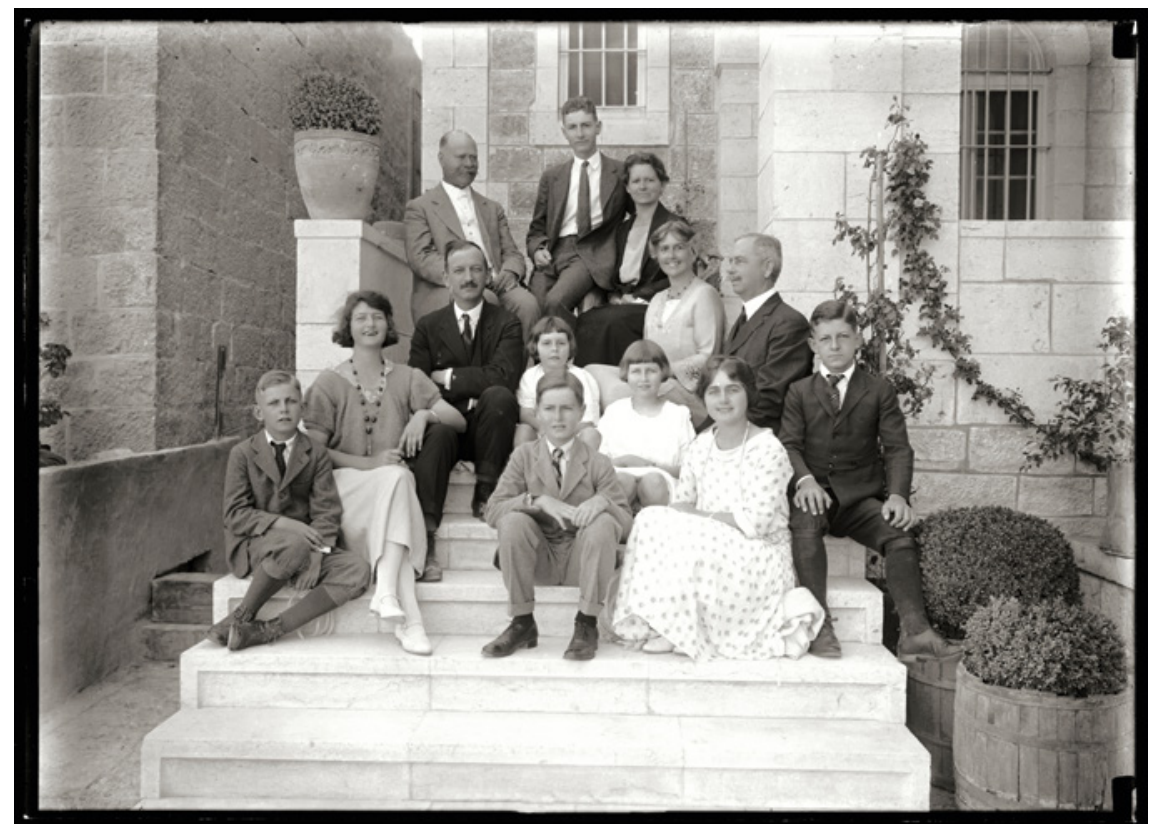

FIGURE 7.4 Group portrait of the Vester and Whiting Families at the American Colony, 1924. With John D. Whiting (third from left up, wearing dark suit). ACPD photographers. Glass Negative. From American Colony Members and Associates, 188os-1930s. Glass Negative Collection AMERICAN COLONY ARCHIVE JERUSALEM 
the land and the Arabic language, became the guides and interpreters of the annual excursions. ${ }^{4}$

The Diary in Photos is a personal account maintained over a span of six years with a range of contrasting, seemingly unrelated themes: historical events, as well as journeys with unusual personalities; wild nature alongside the rich culture of Bedouin tribes; historical sites and royal wedding ceremonies; a turtle laying eggs in the American Colony gardens and stormy demonstrations in the streets of Jerusalem following the publication of the 1939 White Paper, as well as intimate family gatherings and official encounters. As in real life, Whiting's photographic diaries intertwine major events, daily life, family relations, and personal emotive observations.

The progression of photographs follows a chronicle of written diaries that span the years 1905 to $1941^{5}$ but do not cover the entire period. Possibly, some of the diaries were lost. Whiting was a diligent, concise writer. In an abbreviated style, not unlike today's Twitter, he documents his daily schedules and lists his trips on the diary's first pages.

Drove to Laila's house and then to pigeon cave via Ras Beirut.

In Dog river and saw the inscriptions. Sunday, October $27[1907]^{6}$

He writes in order to record dates, locations, weather, people with whom he travels or interacts, historical sites, and major interests. At times, he expands his abbreviated descriptions and uses the data later in carefully written ethnographic and geographic articles. One example is his description of the Samaritan Passover ceremony on Mt. Gerizim (Jarizīm) near Shechem (Nablus) on April 1, 1916, which Whiting published as a limited edition album in Sweden ${ }^{7}$ in 1917 and as an article in National Geographic in January 1920, ${ }^{8}$

4 Lind, "Jerusalem Before Zionism and the American (Swedish) Colony," 209.

5 John D. Whiting, Diaries, John D. Whiting Papers, Manuscript Division, Library of Congress, Washington D.C., Box 1, 1905-1918; Box 2, 1934-1935; Box 3, 1938-1941. See also: Finding Aid to John D. Whiting Papers: https://hdl.loc.gov/loc.mss/eadmss.msoo8123.

6 Ibid., Box 1, 1905-1918.

7 John D. Whiting and Lewis Larsson, Samaritanernas päskfest I ord och bild (Passover Celebrations of the Samaritans in Words and Pictures), Limited edition, no. 159 of 30o, intro. Sven Anders Hedin and Selma Lagerlöf (Stockholm: Albert Bonniers Forlag, 1917); Rare Books Collection, American Colony Archive, Jerusalem.

8 See Yazan Kopty's discussion of John D. Whiting's article, "The Last Israelitish [Israelite] Blood Sacrifice" in this volume. 


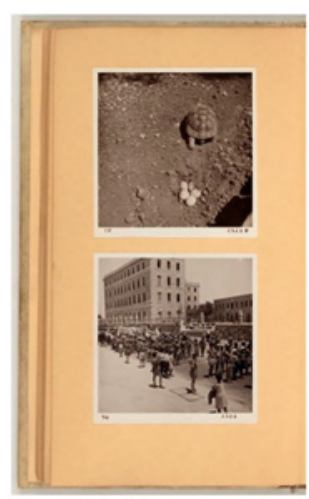

a

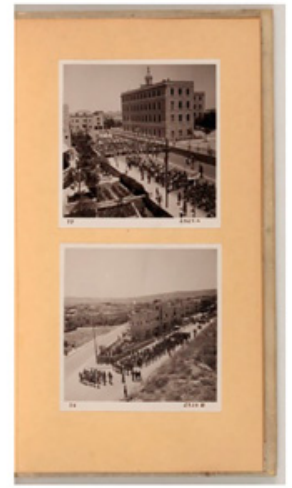

b

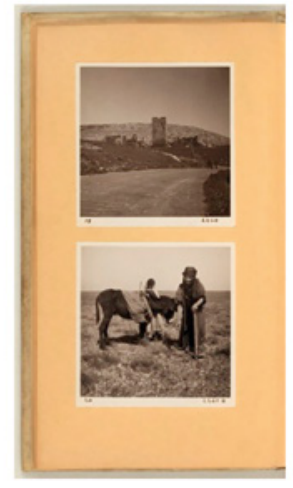

C

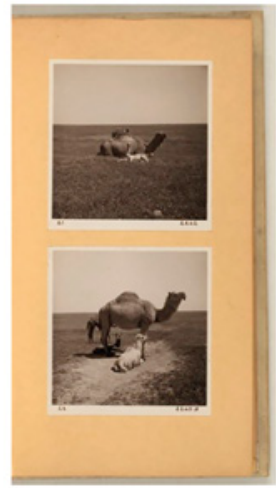

d

FIgURE 7.5 Typical Diary in Photos album pages (from left to right)

a. Tortoise laying eggs / Jewish Protest to White Paper, 1939.

b. Jewish Protest to White Paper, 1939.

c. Iris Trip to Syria. Kasr el Banat / Bedouin woman and boy digging Kimme, 1939.

d. Iris Trip to Syria, Camel calf just born, 1939.

Diary in Photos, Volume V, 1939. Visual Materials from the Papers of John D. Whiting PRINTS AND PHOTOGRAPHS DIVISION, LIBRARY OF CONGRESS, WASHINGTON, D.C.

both with Hol Lars (Lewis) Larsson's photographic rendering of the event.9 In the ethnographic articles Whiting published in National Geographic from 1913 to 1940, he links description and interpretation of the present cultures and the biblical ethos. One article, 'Bedouins in the Bible Lands, ${ }_{10}^{10}$ documents a disappearing culture that was replete with charm and depth. Most of his articles are illustrated with the work of the ACPD photographers taken during well planned photographic expeditions.

Between 1934 and 1939, his written diaries follow his visual diaries closely and serve to complement them. While adding the captions to the photographs in the diaries, Whiting often refers to the written diaries.

Whiting served two terms as Deputy Consul of the United States of America from 1908 to 1915, specialising in agriculture and geography. During this period, he published numerous consular reports on issues of commerce and labour,

9 John D. Whiting, "The Last Israelitish [Israelite] Blood Sacrifice: How the Vanishing Samaritans Celebrate the Passover on Sacred Mount Gerizim," National Geographic Magazine XXXVII (January 1920): 1-46, https://archive.org/details/lastisraelitishboowhit/ page/42/mode/2up.

10 John D. Whiting, "Bedouin Life in Bible Lands. The Nomads of the 'House of Hair' Offer Unstinted Hospitality to an American," National Geographic Magazine, LXXI (January 1937): 58-83. 


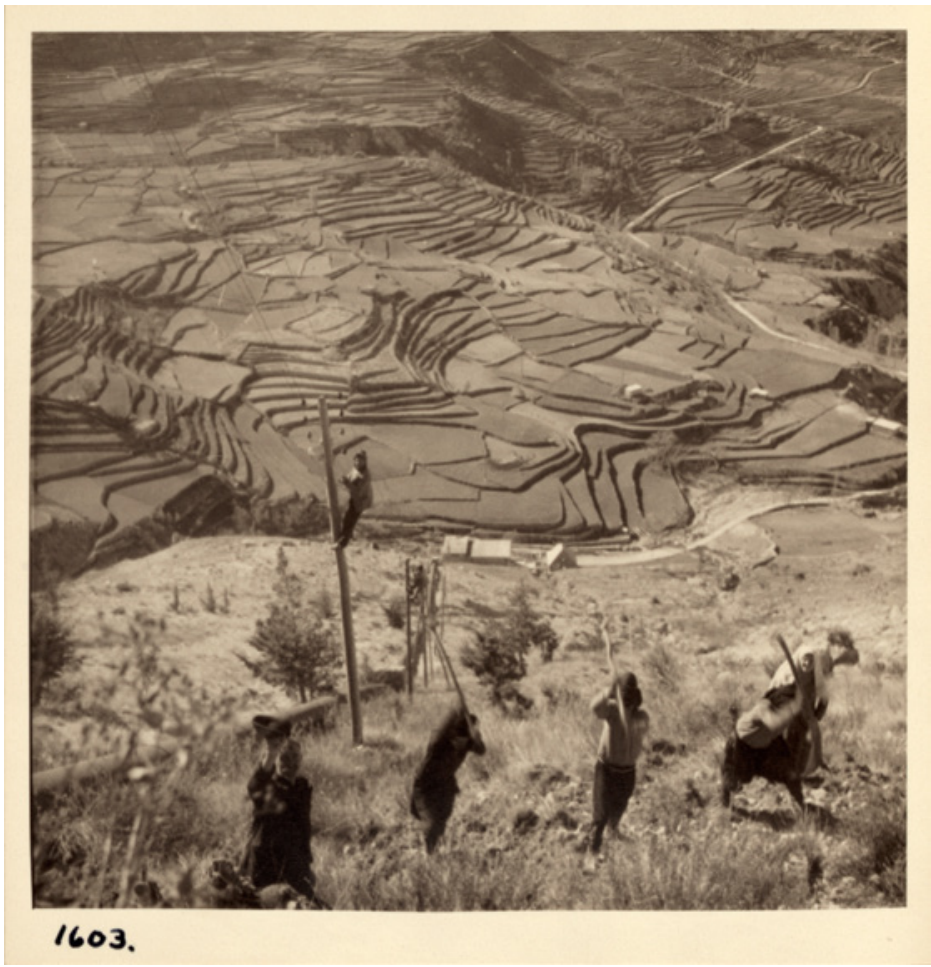

FIGURE 7.6 To Syria with the Bowens, 1oth-2oth December. Lebanon reforesters at work, 1937. From John D. Whiting's Diary in Photos, Volume II, 1936-1937. Photograph album. Visual Materials from the Papers of John D. Whiting PRINTS \& PHOTOGRAPHS DIVISION, LIBRARY OF CONGRESS, WASHINGTON, D.C.

archaeology and, presciently, animal welfare. ${ }^{11}$ His 19 th July, 1909 report is titled 'Railroads in Far East, Description of the Damascus Mecca Line..$^{12}$ During the First World War, he joined the Red Crescent emergency medical service. Along with other Colony members, he initiated several projects for the welfare of Jerusalem residents, including a day centre for women and children, a soup kitchen and military hospitals in Jerusalem. In $1918,{ }^{13}$ he began working for the British Secret Intelligence Service, updating geopolitical maps and serving

11 John D. Whiting. Consular and Trade Reports, 1909-1915. John D. Whiting Papers, Manuscript Division, Library of Congress, Washington D.C., Box 16, 1909-1915.

12 Ibid.

13 See Karène Sanchez Summerer Norig Neveu chapter in this volume related to Jaussen's information-gathering for the French during the same period. 


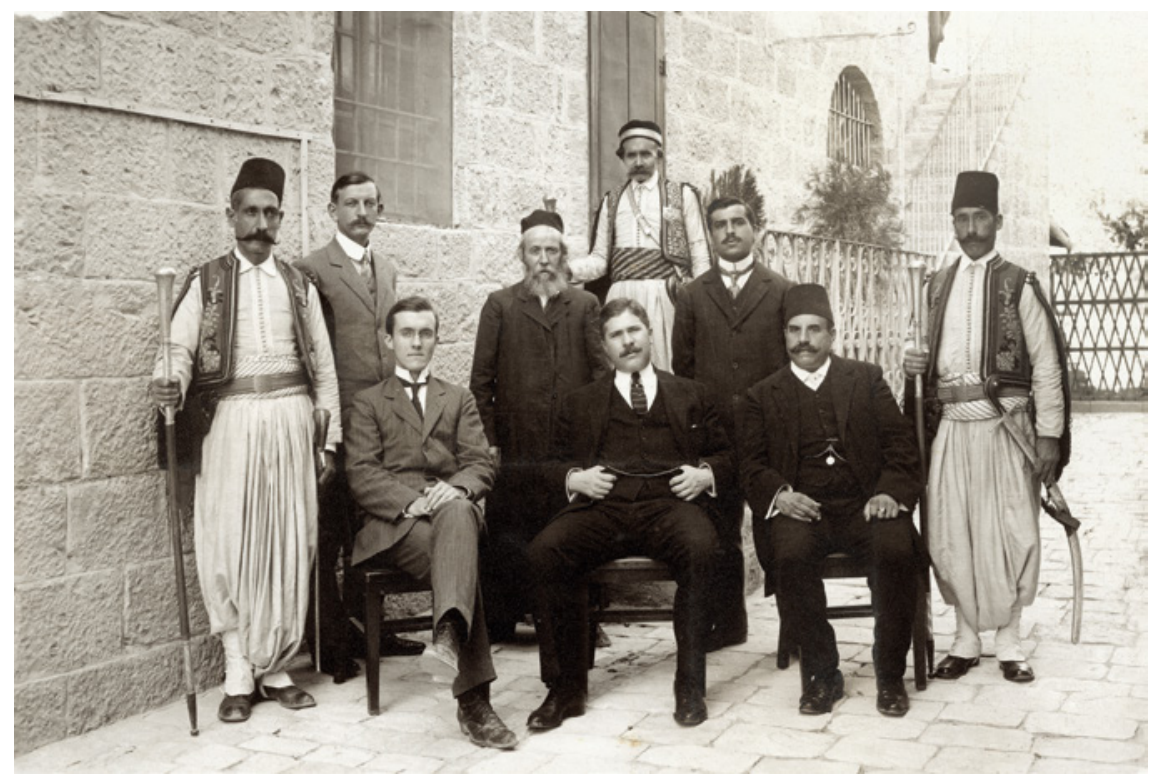

FIGURE 7.7 Staff of the American Consulate, Jerusalem, 1910-1914. With William Coffin, Consul General of United States of America, John D. Whiting (second from left, leaning against the wall), Deputy Consul, the qawās (consular guards) and others. Photographer unknown. From Early Photographs of the American Colony, 1870-1925, Photograph album.

AMERICAN COLONY ARCHIVE JERUSALEM

as an interpreter in Arabic. ${ }^{14}$ At the same time, Whiting collaborated with architect Charles Robert Ashbee (1862-1942), the civic advisor of the City of Jerusalem, ${ }^{15}$ and the Pro-Jerusalem Council, a multicultural decision-making body, founded by Sir Ronald Storrs to prepare restoration plans for Jerusalem and its surrounding neighbourhoods. Whiting and the other American Colony members developed close relationships with the British Mandate's government's leaders who would often dine and stay the American Colony.

14 John D. Whiting, handwritten note describing his work for the British Secret Intelligence Service in 1918. American Colony Archive, Jerusalem. The note compares John D. Whiting's role in the map division of the British Secret Intelligence Service to that of Aaron Aaronsohn (1876-1919), who did similar work in northern Palestine. The note appears to be a personal statement of John D. Whiting, but it is not signed.

15 Jerusalem, 1920-1922, Being the Records of the Pro-Jerusalem Council During the First Two Years of the Civil Administration, by Ashbee, C.R. (Charles Robert Ashbee, 1863-1942), https://archive.org/details/jerusalem19201920oashbuoft. 
The scope of the corpus precludes extensive analysis within the confined context of a chapter, but there are several interlinking themes that help to frame it. First, it gives us some insights into the cultural complexity of identity in the British Mandate period to which Whiting's albums correspond. Second, the albums reveal how Whiting's position facilitated international exchanges. Third, it shows how Whiting's genre of photographic diaries affects our reading of them.

\section{1 \\ Identity and the Complexity of Belonging}

Whiting was part of the American Colony Photo Department from its founding in 1896 until its dispersal in 1934. Yet, these diaries express his own personal viewpoint, not that of the collective. His statement is as an individual photographer and is simultaneously investigative, documentary, and particular. It reflects his own life, the reality of the Middle East, its permanent and temporary residents, the political transformations of his time and the region's natural and cultural landscapes.

Whiting was born in Jerusalem in 1882, one year after his parents John and Mary Whiting and his sister Ruth immigrated to Palestine from Chicago, along with the founders of the American Colony community, Horatio Gates Spafford and Anna T. Spafford. The original community of seventeen Americans and two British aspired to witness a spiritual awakening and hoped to witness the lost glory of Jerusalem restored. They settled on a high hill inside the Muslim Quarter of Jerusalem's Old City, between Herod's Gate and Damascus Gate. Members lived an ascetic lifestyle and purified themselves in anticipation of the messianic event by doing good works for others.

In 1896, when Whiting was fourteen, the American Colony expanded and absorbed a new group of some 120 men, women, and children, seventy-seven of whom were Swedes with a similar messianic, millenarian identity. Unexpectedly, several of the younger generation expanded the boundaries of the sect from religious messianism to a secular ethic that sanctified the everyday acts, and became active participants in Jerusalem's commercial and cultural life as well as in the dramatic changes that affected the region. Others awakened from their idealistic dream only to be shattered by the harsh reality of communal life in Jerusalem, which led them to abandon the collective.

Whiting came of age at a time when Jerusalem was inundated with Americans and Europeans making pilgrimage, research or leisure tours to the Holy Land. Many stayed at the American Colony guest house and participated 
in the commune's internal social dynamic. Leading Christian archaeological research institutions were established near the Colony in the Sheikh Jarrah neighbourhood. Some became close collaborators with the Colony and were assisted by Whiting's extensive knowledge of the Land and its archaeology.

Like other members of the Colony, Whiting spoke fluent Arabic. While still a young adult he travelled extensively in the Jerusalem environs and beyond. The people he met during these journeys became friends for life, were they locals or foreigners who temporarily resided in the Holy Land. He had great admiration for the leaders of the Bedouin tribes and their customs, making repeated visits to their tents, attending their ceremonies and exploring their culture. He visited them alone as well as with his family and community or with guests whom he escorted on guided tours. A few of his Arab friends who studied in the first integrated school in Jerusalem established by the Colony became leaders in Jerusalem and Mandate Palestine. ${ }^{16}$

A good example of the complex space which the American Colony in Jerusalem, ${ }^{17}$ and indeed Whiting himself, occupied was in April 1935, when Whiting accompanied Sir Edgar Horne, politician and chairman of British Prudential Insurance Company, on a fourteen-day tour of the entire Middle East. Whiting orchestrated the trip for Horne and his entourage, including flights and meetings with Haj Amin Husseini (1897-1974), the Grand Mufti of Jerusalem. The journey began in Cairo and passed through Jerusalem. The group continued to the newly built (1932) water-activated power station at Nahārayīm, which was partially sponsored by the Prudential Company on land purchased from Amīr 'Abdallāh. There, the group met with Zionist engineer Pinchas Rutenberg, who had envisioned the project and brought it to completion. From Nahārayīm, the delegation went on to visit Tiberias and Beirut. ${ }^{18}$

16 Lars E. Lind, "Jerusalem Before Zionism and the 'American' (Swedish) Colony," Lars E. Lind Papers (1979), Manuscript Division, Library of Congress, Washington D.C., Box 2, 244.

17 'American Colony in Jerusalem' relates to the historical name of the community active in Jerusalem between 1881 and 1948. The American Colony Hotel, established early in the 195 os is owned today by descendants of the historical community.

18 John D. Whiting, Diary in Photos Vol. I, part 2, 1935. "To Petra with Sir Edgar Horne; Edgar Horne in Syria; Visual materials from the papers of John D. Whiting, Prints and Photographs Division, Library of Congress, Washington, D.C., https://www.loc.gov/ resource/ppmsca.17161/?sp=2\&st=gallery (Images $51-63$ in the full-page digital album version). 
The photographed series of the journey with Horne consists of 26 photographic prints and begins on a page that displays the final image from Whiting's previous tour, a flock of storks against a cloudy sky. Under this photograph, Whiting placed a snapshot taken from the interior of Sir Edgar Horne's room in the Shepherd Hotel in Cairo. The lens looked out onto the hotel garden surrounded by trees, fountains, gazebos and seating areas. In contrast to the schema of thematic albums, Whiting juxtaposes subtle visual transitions when shifting narratives, with thelandscapeoften becomingthebinding element between the stories. The series ends with Sir Edgar in silhouette in Nāqūra, leaning on a rock, gazing towards the Mediterranean, holding a branch in one hand and a cup of tea in the other. Whiting's photographs rarely include close-ups. In the thumbnail compilation of photographs, the landscape is a dominant feature. For the most part of this series, the individual subject, sometimes unidentifiable, is seen in miniature against an open landscape, whether natural, archaeological or urban. Whiting amalgamates his subjects within the landscapes of the Levant as a contextual element. This he applies to photographs of Sir Edgar and his entourage as well as to photographs of a Domari girl and her brother as she dances before guests on the road to Jerash.

On 8th April, Whiting photographed Horne and a member of the entourage, Mr Lever, at the airport with an Imperial Airways airplane seen at background. They took off and flew over the Gulf of Suez, while Whiting photographed from the air the mountainous landscape of the Gulf, the city of Suez (Suwās) and Fort Tawfiq port. In his diary on that day, Whiting wrote:

We reached Abuassi airport, where a three-engine Imperial Airways airplane awaiting us. Took seats after being weighted etc. Started at 8.11 and left around 8.13. [...] At 8:30 flying at $4500 \mathrm{ft}$. 10:15 bumpy $5000 \mathrm{ft}$. up. 10:15 Gulf of Arabia sight. [...] 10.55 over Petra Valley, 6500 ft. up. [...] 11:40 landed on Fjord (?). [The flight] was bumpy all the time after first recorded. Sir Edgar [Horne] slept and read a lot, said he was scared [...] Reached Cook camp by 3:30 p.m. Beer and tea and then took Mr. Lever to the Crusader castle and down Wad [valley] Syngh [near Petra].[...] Captain Loraine piloted plane helped by Mr. Coster. ${ }^{19}$

On 13th April, Horne picked up Whiting at the American Colony store at Jaffa Gate. They visited Bethesda pool in the Muslim Quarter of the Old City of

19 John D. Whiting, Diaries, John D. Whiting Papers, Manuscript Division, Library of Congress, Washington D.C., Box 2, 1934-1935. 


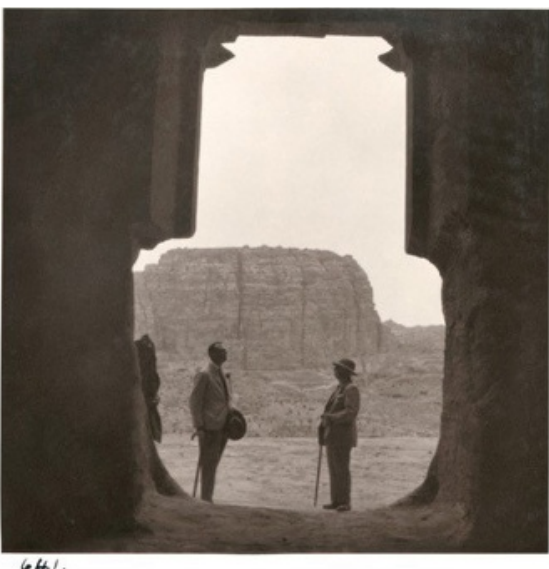

a

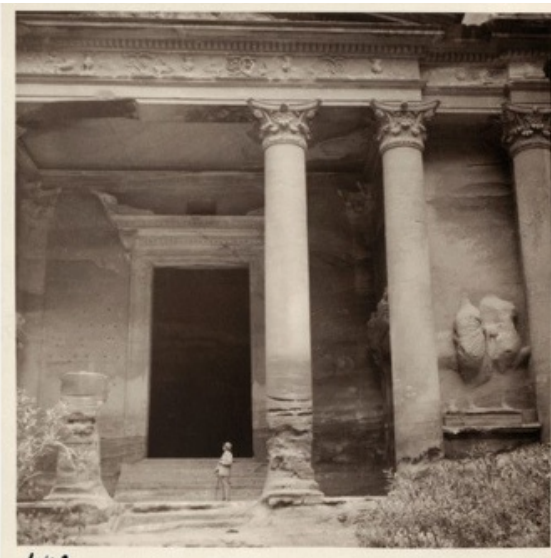

642.

b

FIGURE 7.8 Trip to Petra and Syria with Sir Edgar Horne and Mr Lever, 1935

Note: The four photograph compilations illustrating the highlighted series is a partial selection from the complete album series. Please follow the footnotes links to see the full album pages series.

a. Sir Edgar and Mr Lever. Tomb of the Urn, Petra, 1935.

b. Sir Edgar at El Khazna, Petra, 1935.

c. Mr Lever on top of the Crusader Castle, Petra, 1935.

d. Sir Edgar [Horne] in the siq, Petra, 1935.

From John D. Whiting, Diary in Photos, Volume I, Part II, 1935. Photograph album.

Visual Materials from the Papers of John D. Whiting

PRINTS AND PHOTOGRAPHS DIVISION, LIBRARY OF CONGRESS,

WASHINGTON, D.C. 
Jerusalem and the Temple Mount area. On the morning of April 17th, Whiting with Horne met with the Grand Mufti for a long interview. Earlier that week, Whiting accompanied Mr Lever and Mr Muelford to a meeting with the Grand Mufti, who asked the Prudential officials for a loan of 100,ooo pounds for the purchase of land and the construction of a building in Jaffa. ${ }^{20}$ In the afternoon, Whiting escorted Horne to Bethlehem and Solomon's Pools. They ended their day over tea at the King David Hotel, a central meeting point for the British Mandate officials. On 19th April, Horne and Whiting travelled through Transjordan to Syria. They visited the Temple of Artemis in Jerash and the Nahārayīm power station, where Rutenberg explained the workings of the station to Sir Edgar. In his diary on that day, Whiting wrote:

First thing in the morning found Mr. Joshua Gordon in Hotel trying to telephone us. [...] Mr. Asherwood and Mr. Lever saw him almost at once and made arrangements for visits to Zionist activities [...]. I had a long time alone with Mr. Joshua [Yehoshua] Gordon [Zionist, coordinator between Zionists and British authorities] [...] and was able to tell him about Col. Layton and then brought up questions if I would be wanted in the party. He wanted me to go along. I drove to the German settlements and then to Rutenberg [Nahārayīm power station]. Found both brothers and wife of [Avraham]. After lunch together looked over words and departed. It seems Prudential lent Rutenberg lot of money but it was quickly repaid to Mr. Lever's consternation. We drove through Tiberias on to Nazareth. $[\ldots]^{21}$

The interior shot of the Nahārayìm power station resembles a dramatic scene from Fritz Lang's 1927 futuristic film 'Metropolis', with engineer Pinchas Rutenberg explaining the power station workings to Sir Edgar Horne. Rutenberg's brother Avraham stands beside them with his wife, looking towards the camera, while Pinchas Rutenberg and Horne focus on the explanations. The exterior shot, taken against the massive concrete dam in Nahārayīm, shows the British gentlemen involved in a dialogue at the front, Rutenberg and his brother talking to each other on the right side, while Whiting, who had handed the camera to someone else, is seen standing behind them all, in contemplation, his hands behind his back. These two images manifest the evolving

20 A perusal of his 1935 diaries reveals that Whiting visits the Mufti several times both with guests and in private. He also calls the Mufti to discuss the loan request with him.

21 John D. Whiting, Diaries, John D. Whiting Papers, Manuscript Division, Library of Congress, Washington D.C., Box 2, 1934-1935. 
tensions between the British powers and the Zionists as well as between the Zionists and the American Colony. The diminished scale of the human figure against the dominance of the context, a distinct feature of Whiting photography, is evident here too.

Photographs of the journey show the entourage visiting sites and historical monuments. At times, Bedouins or Domaris penetrate the photograph's frame. The group is seen sitting together in Jerash, conducting a lively intimate conversation against the monumental archaeological landscape. At other times, Horne appears alone against a vast natural backdrop, as in Nāqūra, northern Palestine. Even when Whiting photographs the group in Jerusalem against the Prudential offices in the background, his subjects seem distant and disconnected. This is a group of wealthy tourists with a clear economic interest, which lays an anchor in Palestine during Mandate rule. In the local consciousness, Whiting is considered a well-informed tour guide, and thus his services are procured to escort the respected delegation. He escorts them on their visits to the Mufti and apparently also serves as their translator.

Whiting hesitated visiting the Zionist project. The tension between him and Rutenberg is an indirect manifestation of the rising strains between British
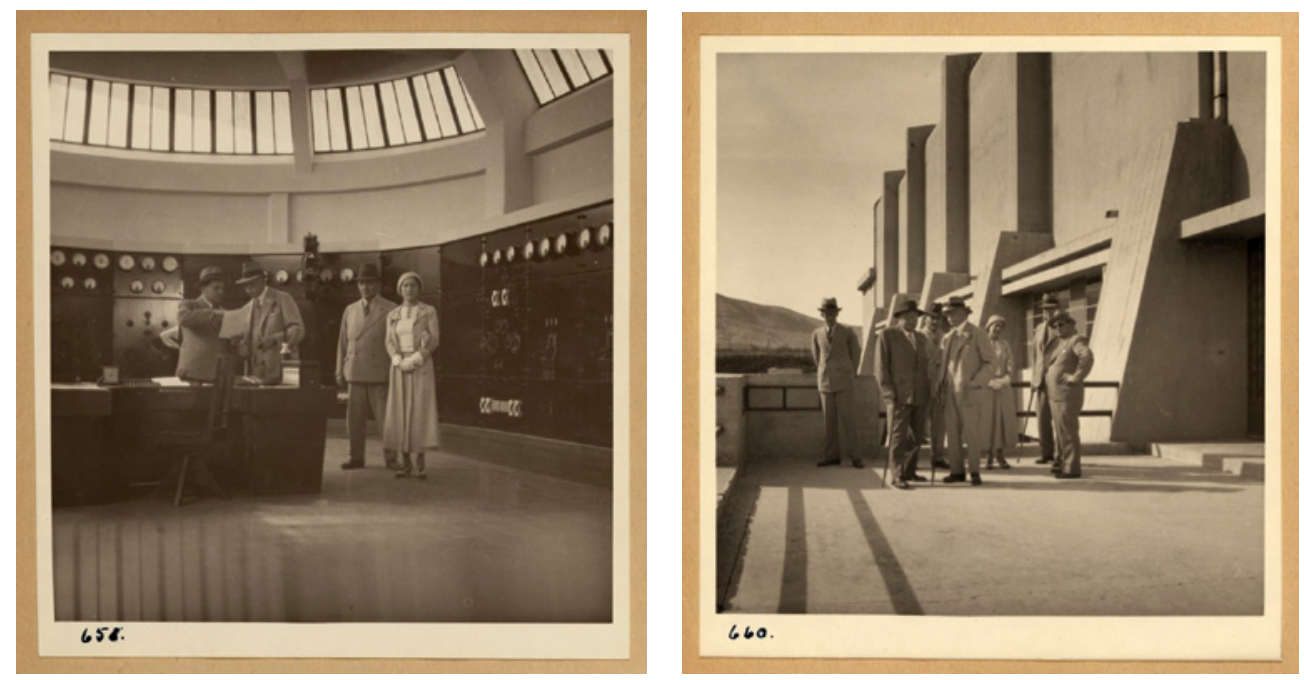

Figure 7.9 AND Figure 7.10 Trip to Petra and Syria with Sir Edgar Horne and Mr Lever, 1935. Left: Mr Rutenberg (younger) explains to Sir Edgar the workings, 1935.

Trip to Petra and Syria with Sir Edgar Horne and Mr Lever, 1935. Right: The party outside the electrical station, 1935. From John D. Whiting, Diary in Photos, Volume I, Part II, 1935. Photograph album. Visual Materials from the Papers of John D. Whiting PRINTS AND PHOTOGRAPHS DIVISION, LIBRARY OF CONGRESS, WASHINGTON, D.C. 
authorities, Palestinians and Zionists. ${ }^{22}$ Whiting was known for his work with the British Secret Intelligence Service and was a close ally of Palestinians and the Mandate officials, and thus, Rutenberg might have considered him as persona non grata. Yehoshua Gordon, the coordinator between the Zionists and the British Mandate authorities, convinced Whiting to join the tour despite his hesitations.

In 1935, Whiting's political position was located at the juncture between the Palestinians, represented by his close ties with the Mufti Hājj Amīn al- Husaynī, and the British authorities. The identity of the American Colony as a neutral entity throughout the Ottoman rule and in the early twentieth century enabled its members to develop close ties with Palestinians, who frequented the Colony premises and institutions and developed friendly relationships with its members. The violent struggles however, between Palestinians and Zionist changed the political map and skewed the location of the American Colony's identity in relationship to British. Aside from the encounter at Nahārayīm and Whiting's long conversation with Yehoshua Gordon, this series documents the visit of the Prudential president and delegation as a potential business-oriented tour.

Mary Roberts and Jocelyn Hackforth-Jones ${ }^{23}$ attempt to contrast the term 'stereotypical stasis' with cultural processes when iconographic conventions cross borders between East and West. They claim that multiple cultural identities have mutual influence, and their implications must be studied. The Orientalist practice modifies its central position in defining the exotic 'other' to transpositions of ideas from one disciplinary field to another. ${ }^{24}$ These researchers cite Fred Bohar, who examines the term 'period value'. This term asserts that photographic content is accessible to the viewer long after it is created, in a manner different than the accessibility of conventional academic textual knowledge. We must study, claim Robert and Hackforth-Jones, what is defined as 'the connected world of empires' to discover intercultural connections that were ignored when the focus is concentrated solely on the parameters of imperialist European cultures. ${ }^{25}$

The movement between Orientalist tropes and the connected histories that 'period value' yields, shows the complexities of relating to indigenous cultures that cannot be ignored. Entirely compressing such complex bodies of work into Orientalist paradigms forces the reader to adopt this viewpoint

22 Ibid.

23 Jocelyn Hackforth-Jones and Mary Roberts, "Introduction: Visualizing Culture across the Edges of Empires," in Edges of Empire: Orientalism and Visual Culture, eds. Jocelyn Hackforth-Jones and Mary Robert (Oxford: Blackwell Publishing, 2005), 2.

24 Ibid., 15.

25 Ibid., 17. 
as the dominant history while ignoring the 'period value' encoded in the photographs. Multi-faceted narratives are the only accounts capable of contradicting erroneous stereotypes and collective interpretations. This act of 'writing and interpretation becomes a true mission, capable of recharging the collective memory with components that were deleted from it because they were read incorrectly'. ${ }^{26}$

By contrast, should academic research choose to examine photographs from an aesthetic or exotic viewpoint alone, the photographs lose parts of their historical narrative. At its heart, they encode the identities of individuals and groups and the complex relationships among these identities. Micklewright asserts that in the past thirty years, the term 'Orientalist' has been used broadly, without critical reflection. The individuals who collect, preserve, display and print such collections must adopt the interpretive potential contained in this fluid diversity of identities, instead of compressing it into the grey category of Orientalism. ${ }^{27}$

Volume I of the Diary in Photos includes six photographs from the grandiose wedding of Amīr Talāl in Amman. ${ }^{28}$ A complementary set of fifteen photographs of the wedding ceremony taken by Whiting on the same day constitutes part of Whiting's thematic photographic series titled 'Bedouins in Jordan and Other Locations'. Here, Whiting focuses on the Bedouins depicted during the wedding festivity customs. ${ }^{29}$

Sorenson, David [Whiting], Jock [Vester], and myself rode in the car to Amman. We arrived in the afternoon and discovered that the wedding procession had already begun. This was the wedding of Emir Talal, the son of Emir Abdullah. The procession began at the Parliament building

26 Woodward, "Creating Memory and History," 27.

27 Nancy Micklewright, "Orientalism and Photography," in The Poetics and Politics of Place: Ottoman Istanbul and British Orientalism, eds. Zeynep Inankur, Reina Lewis, and Mary Roberts (Seattle, WA: University of Washington Press, 2011), 106.

28 John D. Whiting, Diary in Photos, Vol. I, 1934-1935, "Wedding of Emir Talal," 26-27 Nov. 1945. Visual materials from the papers of John D. Whiting. Library of Congress, Washington, D.C., https://www.loc.gov/resource/ppmsca.17161/?sp=1\&st=gallery (Pages $35^{-3} 8$ in the full-page digital album version).

29 John D. Whiting, Bedouins in Jordan and Other Locations, 1934-1935, https://www.loc.gov/ pictures/item/2007682814/ (Pages 29-37 in the full-page digital album version). 
and continued to the palace. Bedouins on horses, with swords. The mahmal [bridal tent] from Damascus was mounted on a large camel and escorted by two Circassian [guards], each bearing an Arab flag. Several Bedouins wore armour on their backs. Sorenson and I ran after the group to the palace and took good photographs. ${ }^{30}$

One of these photographs (Fig. 7.11), shows Amīr 'Abdallāh standing on the palace entrance steps, with Bedouin and Circassian representatives on his left and a group of British Mandate representatives in uniforms on his right, all gazing at the camera. The current group of photographs includes a scene of the procession accompanying the bride who rides in the traditional mahmal tent mounted on a camel. They lead the bride towards the palace, her escorts alongside. Next, we see a parade of Bedouin knights on horseback, wearing plated armour, with round metal shields hung across their backs and swords in hand. Another photograph shows preparation of the feast for the 'tribes' outside the palace. The high commissioner is hosted at the king's table at noon and Palestinian dignitaries attend the evening reception. A close-up of the king's noble horse is excluded by Whiting when editing the Diary in Photos, but appears as part of the same event in the thematic album Bedouins in Jordan and Other Locations. ${ }^{31}$

The relationship between Whiting and King 'Abdallāh of Transjordan is evident in ACPD photographs beginning in 1921, when Whiting met Abdullah and other dignitaries at a ceremony held at Augusta Victoria, then the British Civil Administration headquarters. At the ceremony, Abdullah accepted the offer of Winston Churchill, Herbert Samuel, and T.E. Lawrence to rule Eastern Transjordan under British Mandate authority. This event was photographed in detail by the ACPD photographers as depicted in the World War I and the British Mandate in Palestine, 1917-1926, photograph album. A second encounter between Mandate leaders and Abdullah took place in April of that year near Amman, and was documented by Colony photographer Lewis (Hol Lars) Larsson. Whiting participated in the event and hobnobbed with Emir 'Abdallāh, T.E. Lawrence, and other Mandate dignitaries. ${ }^{32}$

30 John D. Whiting, Diaries, John D. Whiting Papers, Manuscript Division, Library of Congress, Washington D.C., Box 2, 1934-1935.

31 John D. Whiting, Bedouins in Jordan and Other Locations, 1934-1935. Photograph Album. Visual Materials from the Papers of John. D. Whiting, Prints and Photographs Division, Library of Congress, Washington, D.C.

32 Hol Lars (Lewis) Larsson, ACPD photographers, Meetings of British, Arab, and Bedouin Officials in Amman, Jordan, April 1921, photograph album, https://www.loc.gov/item/ 2007675257/. 


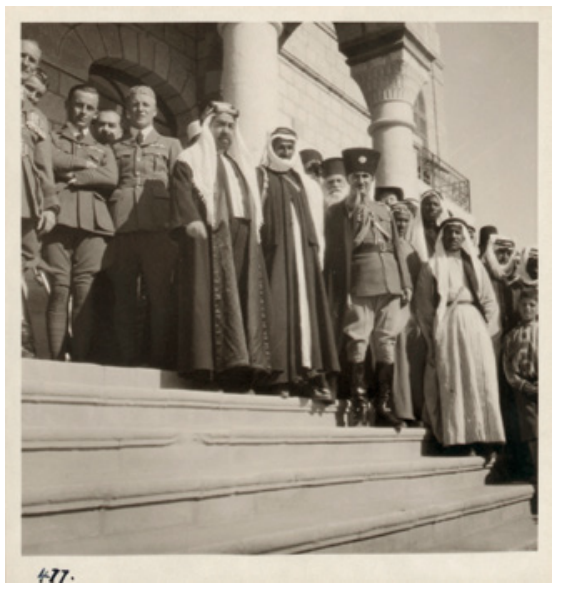

a

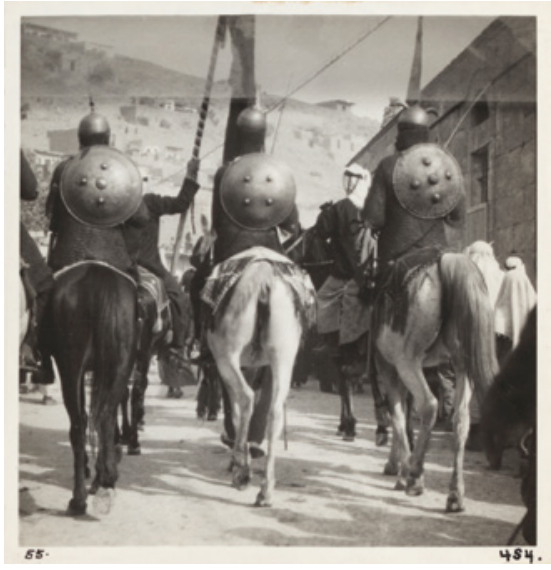

b

FIGURE 7.11

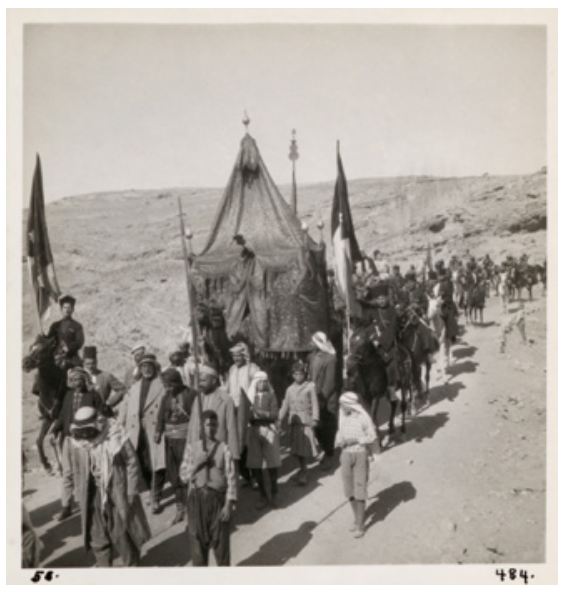

C

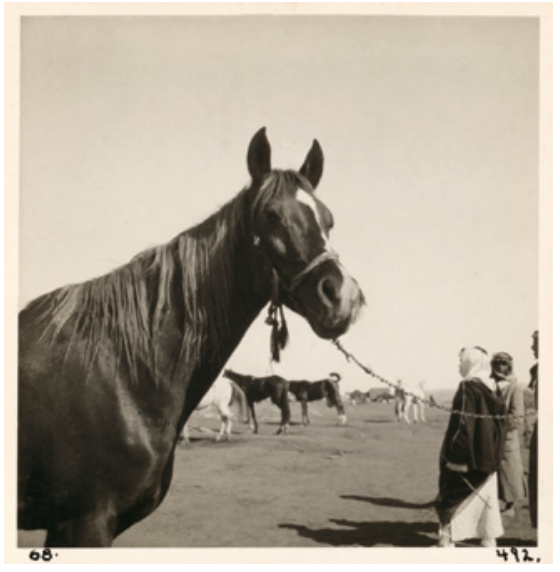

d

Wedding of Emir Talal (Amīr Țalāl), Amman, November 26 \& 27, 1934. a. Emir Abdullah (with Shaykh Mutgal el Fiez) watching the procession passing palace, 1934 .

b. Bedouin Warriors in medieval armour, 1934.

c. Returning from the Palace. 'The mahmal', 1934.

d. Emir Abdulla's Horse, 1934.

From John D. Whiting, Diary in Photos, Volume I, 1934. Photograph album.

From John D. Whiting, Bedouins in Jordan and Other Locations, 1934-1935.

Photograph album. Visual Materials of the Papers of John D. Whiting PRINTS AND PHOTOGRAPHS DIVISION, LIBRARY OF CONGRESS, WASHINGTON, D.C. 


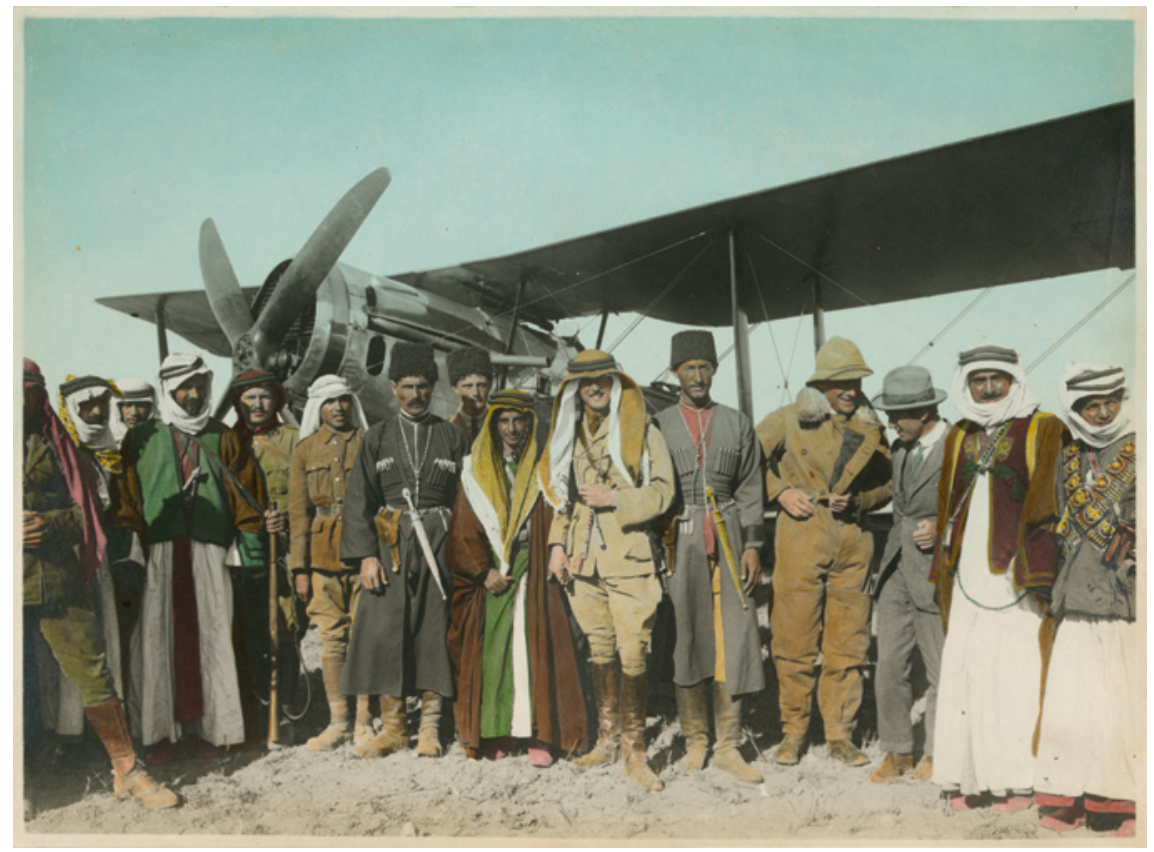

FIGURE 7.12 Bedouin and Circassian Leaders, Amman, April 17, 1921. With T.E. Lawrence (third from right in grey suit and hat) and John D. Whiting (sixth from right), posing with an airplane and pilot at Amman Jordan. From Meetings of British, Arab and Bedouin officials, Amman, Jordan, 1921. Photograph album. Hol Lars (Lewis) Larsson, ACPD. Visual Materials from the Papers of John D. Whiting PRINTS \& PHOTOGRAPHS DIVISION, LIBRARY OF CONGRESS, WASHINGTON, D.C.

Given Whiting's tenure as Deputy Consul and his position in British Mandate society, one of the series in the 1934 volume of the photographic diaries that has particular resonance represents an event that took place in September when Whiting escorted Ely E. Palmer (1887-1977), the newly appointed Consul General of the United States of America in Jerusalem and his wife on a three-day trip to southern Palestine, at the invitation of 'Ārif al-'Ārif. They were joined by Whiting's wife Grace, their son Wilson, Anna Grace Vester Lind (daughter of Bertha Vester, Grace's sister) as well as Mrs. Rolston and Whiting's dog Barak. Whiting and his party stayed at 'Ārif al-'̄Arif's Bedouin camp and watched camel and horseraces in Gaza. 'Ārif al-Ārif prepared a Bedouin tent for the men and a new British tent for the women. He sent a cook and a waiter 
to provide his guests with the city-style dishes to which they were accustomed. Riding on camels and horses, they travelled back and forth from Gaza to the camp in Dayr al-Balah. ${ }^{33}$

'Ārif al-'̄rif (1892-1973) was a Palestinian journalist, politician, writer, and historian who studied in Istanbul and worked as a journalist and translator for the Foreign Office. During the First World War, he served as an officer of the Ottoman Empire, was captured on the Caucasus front, and sent to a prison camp in Siberia. While in prison, he edited a handwritten newspaper and translated the writings of Ernst Heinrich Haeckel (1834-1919; German zoologist, naturalist, philosopher, physician, and artist) into Turkish. After the Russian Revolution, 'Ārif al-'̄Arif returned to Palestine, where he became a political activist and editor of the Syrian newspaper Süriyya al-Janübiyya, the first Arabic nationalist newspaper published in Jerusalem. ${ }^{34}$

'Ārif al-'Ârif took part in the Nabi Musa festival of 1920, which led to mass riots during which he was arrested. After he was released, he fled to Syria with Hājj Amīn al- Husaynī (1895-1974), the Grand Mufti of Jerusalem. Later he advised the Palestinians against violence, and encouraged them to adopt 'the quiet, courage and discipline of their opponents. ${ }^{35}$ In Damascus, he became Consul of the Syrian Congress, founded the Palestinian Arab Society and became its general secretary. After the French invaded Syria in 1920, he fled to Transjordan, returned to Jerusalem, and became district officer of Beersheba and later of Gaza. After 1948, he became Ramallah's district officer and director of the Palestine Archaeological Museum, now the Rockefeller Museum.

The photographic series of this journey depicts the small group of guests and hosts in a quiet, relaxed atmosphere at the Gaza seashore. ${ }^{36}$ Whiting's selective compilation of eight photographs depicts the narrative elements carefully. He first presents the party watching the Gaza races, without showing us the races, and on the same page exposes the setting of the camp, with a tree and camels kneeling at front. The locals are presented next, with one of

33 John D. Whiting, Diaries in Photos Vol. I, 1934-1935, "Bedu [Bedouin] Camp at Deir el-Belah [Dier al-Balah,]" (29 Sept.-1 Oct. 1934), in Visual Materials from the Papers of John. D. Whiting, 29-32, Prints and Photographs Division, Library of Congress, Washington, D.C. https://www.loc.gov/resource/ppmsca.17161/?st=gallery (follow images $25^{-28}$ in the full-page digital version).

34 Bernard Wasserstein, "Clipping the Claws of Colonisers': Arab Officials in the Government of Palestine, 1917-1948," Middle Eastern Studies 13, no. 2 (1977): 171-194.

35 Ibid.

36 John D. Whiting, Diaries in Photos, Vol. I, 1934-1935, "Bedu [Bedouin] Camp at Deir el-Belah [Dier al-Balah.]" (29 Sept.-1 Oct. 1935 https://www.loc.gov/item/2007675295/ (follow images $25^{-28}$ in the full-page digital version). 


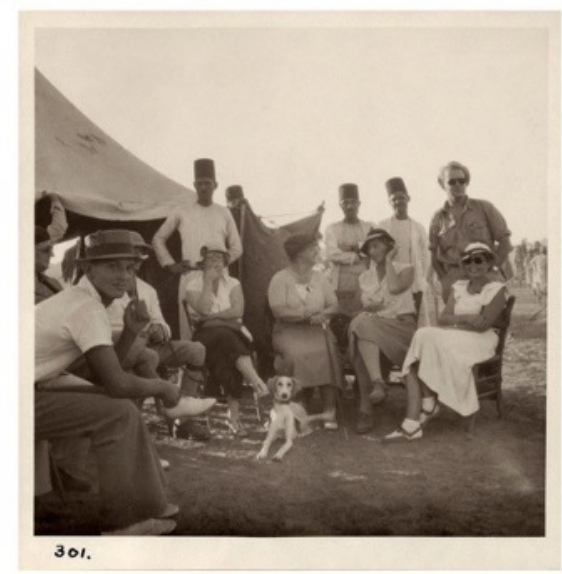

a

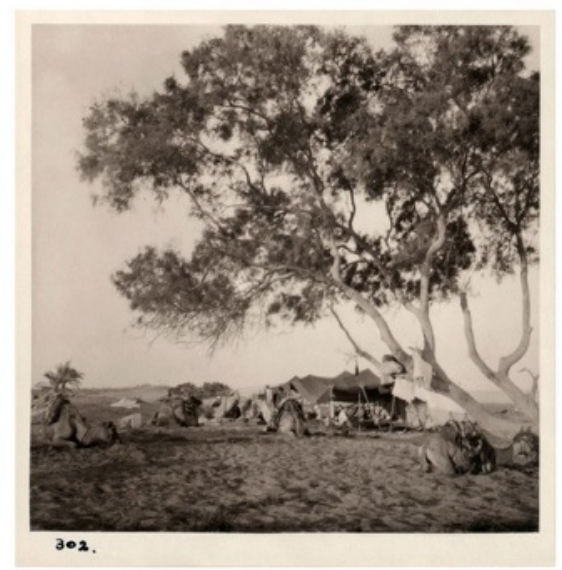

b

FIGURE 7.13

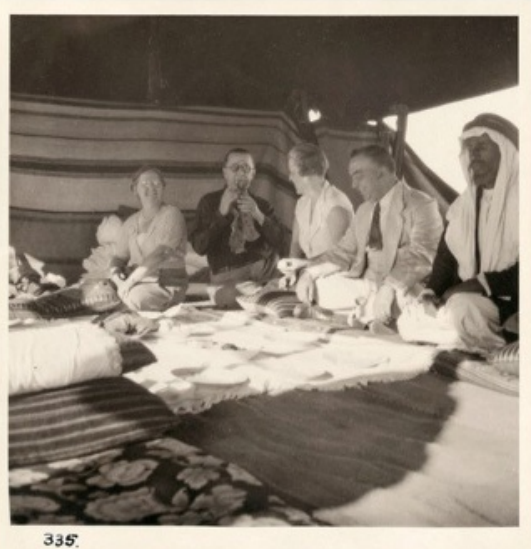

$\mathrm{c}$

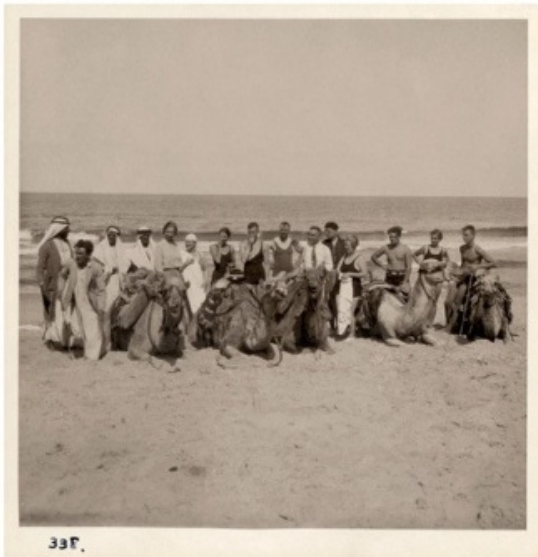

d

Bedu Camp at Dayr al-Balaḥ. Invitation of 'Ārif Bay, Sept. 29-Oct.1, 1934

a. Watching the Gaza races.

b. The camp near Deir el Belah, 1934.

c. Lunch in Bedouin tent. Grace [Whiting], Mr. Palmer, Mrs. Palmer, 'Ārif Bay and the Sheikh

d. The party on the sands

From John D. Whiting, Diary in Photos, Volume I, 1934. Photograph album.

Visual Materials from the Papers of John D. Whiting

PRINTS AND PHOTOGRAPHS DIVISION, LIBRARY OF CONGRESS,

WASHINGTON, D.C. 
the hosts, and a 'Gypsy' (Domari ${ }^{37}$ ) belly dancer entertains the guests, while a musician plays for her. Interior tents scenes follow with the amusing image of Consul Palmer on his knees shaving in front of a hand mirror and, in another tent, the party sitting together after lunch enjoying conversation with 'Ārif al-Ārif. The next image takes us outside again to show 'Ārif al-Ārif's 'ladies' tent, and the series concludes in a magnificent scene of Bedouin hosts with guests in swimming costumes, posing for Whiting's camera behind a row of kneeling camels, against the sea of Gaza.

Whiting's lens is as light as his pen. In his scenes, not one personality appears more important than any other. 'Ārif al-'̄rif plays the gracious host. He enables the guests to set aside their usual formal diplomatic manners and indulge in each other's company, enjoying the atmosphere, sea, sand dunes, races, music and local dancing. This scene is a climactic encounter between 'Ārif al-Ārif, Ely E. Palmer, John D. Whiting and his family, Bedouins, and the sheikh of Dayr al-Balah. Whiting knew each of the personalities, and he made the connections between Palmer and his wife and 'Ārif al-'Ārif, thus offering an informal setting for diplomatic relationships.

The setting seems to enable the guests to free themselves from the social conventions that characterised European and American diplomacy. Likely, the encounter supported the development of emotive and intellectual sharing between the guests and their hosts, under Whiting's and 'Ārif al-'̄rif orchestration. Based on this series and other series in the Diary in Photos corpus, Whiting and 'Ārif al-'̄rif apparently had a close friendship nourished by their common interests.

Palmer arrived in Palestine on 11th March, 1934, on board the steamer Excalibur. The Tel Aviv municipality held a formal reception in his honour at Beit Ha'am (a cultural meeting place). Before commencing the voyage, Palmer had met with representatives of the Jewish community at the Pennsylvania Hotel in New York. Community leaders expressed the hope that he would enjoy his new position and contribute to transforming Palestine into a joyful, fruitful (Zionist) land. On his part, Ely Palmer declared diplomatically that he took a broad view of his appointment in Jerusalem and that he was interested not only in 'friends', but also in foreigners. In contrast, it seems that Whiting

37 The Doms are a people related to the Romani of Europe. Sometimes they are referred to as 'Gypsies' or 'Middle Eastern Gypsies' in English, and 'Nawar' in Arabic. In Palestine, they specialised in two particular trades, metalwork and entertainment. See Yaron Matras, "Two Domari Legends About the Origins of the Doms," Romani Studies, $5^{\text {th }}$ series (10, 2000): 53-79. 
organised the meeting in Dayr el-Belah in order to promote diplomatic relations between Palmer and 'Ārif al-'Ārif.

\section{5 To Palmyra with Cromwell Party, 15th-19th April, 1938}

Perhaps one of the more curious themes of Whiting's visual diaries is the series of 24 photographs documenting the visit of tobacco heiress Doris Duke Cromwell (1912-1993) in Damascus and Palmyra. After her wedding in 1935 to James Cromwell, the couple began a well-planned honeymoon trip around the world. During the trip, Doris gained an appreciation of the rich Islamic artistic and architectural tradition and began to collect Persian and Middle Eastern and Islamic art for her home in Florida. While the couple were in Hawaii, Doris decided to use these artifacts to decorate her planned mansion in Honolulu instead. Arthur Upham Pope (1881-1969), was an American expert on Persian art and culture and a professor of philosophy and aesthetics who aided the Cromwells in organising the excursion. In March 1938, Doris travelled to Iran and the Middle East for six weeks to purchase Islamic art works for her home in Hawaii, which she named Shangri La. The journey began in Alexandria and the Cromwells visited also Cairo, Luxor, Lydda (Lod), Damascus, Palmyra, Aleppo, Baalbek, Haran, Baghdad, Tehran, Mashad, Isfahan and Istanbul. ${ }^{38}$ Upham Pope booked the Cromwells and their party a private KLM plane for the journey and introduced them to merchants and consultants who appraised their selected items. The Cromwell visited Damascus twice, once in March and second in April and in both events Whiting was present. His written diaries recall both meetings but his visual diaries recall only the April Meeting with the Cromwells in Damascus and Palmyra.

The first meeting with the Cromwells and their party took place in Damascus between 15th and 17th March, 1938 and the second between April 14 and 19 1938. Whiting is called by Georges Asfär of the prominent Damascus-based antiquities firm of Asfār \& Sārkīs (Georges 'Geo' Asfār and Jean Sārkīs) with whom Vester \& Co., the American Colony Store in Jerusalem, had commercial relations, to bring over a rare rug for Cromwells and to consult Asfār and Sārkīs in managing the purchase process. The Cromwells arrived in Damascus on 16th March and Whiting guided them on their first tour of the area. The Cromwell party continued to visit bazaars and markets and Whiting writes that it was

38 John D. Whiting, Diary in Photos, Vol. III, 1938. To Palmyra with Cromwell party, April 15-19, 1938.Visual materials from the papers of John D. Whiting Library of Congress, Washington D.C., https://www.loc.gov/resource/ppmsca.17413/?sp=2\&st=gallery (Follow full-page digital album version, image $42-5^{2}$ ). 
hard to keep track of them'. On 17th March, Whiting meets the Cromwells and joins them with Asfār and Sārkīs in search for additional artifacts. ${ }^{39}$

A month later, On 15th April, 1938, 4:30 a.m. Whiting left the American Colony for Damascus to continue to advise the Cromwells on their purchases of artifacts and as their interpreter of the events in Palmyra. On his way to Damascus, he took a few photos which he titled 'Pipe-line near Afüla [North East Palestine] on fire at dawn' and displayed these as the opening images of this series, to memorialise events in Palestine in contrast to Damascus. With Whiting as consultant, Doris purchased dozens of items worth hundreds of thousands of dollars. ${ }^{40}$ Following their visit in Damascus, the Cromwells travelled to Palmyra on their private KLM plane, escorted by Whiting. At Palmyra, they were received by Asfar and Sarkis as well as local dignitaries including Emir Fawas, leaders of Bedouin and Domari tribes and of the French regime and were hosted by the mayor of Palmyra for lunch. They then attended an impressive, staged performance of camel, horse, and donkey races, and a 'Gypsy' (Domari) wedding. Residents of Palmyra, local Bedouins, and French officers of the Desert Patrol were also present and captured in Whiting's camera.

39 John D. Whiting, Diaries, John D. Whiting Papers, Manuscript Division, Library of Congress, Washington D.C., Box 3, 1938-1941. Whiting's 1938 diary consists of detailed descriptions of the Cromwells artifacts purchase process. Whiting writes in his diary: March 17 Thursday - Damascus; Cromwell. Ran out to see the reed flute maker and then to glass works and settled acts and chose few pieces and designed some Jordan water bottles in Ammonite shape. Met Geo [Asfar] and party [the Cromwells] at Asfar store at 10. We took them out in search of upholstering Persian shawl designs. It early became evident that they wanted to go alone. We left them and after a time they (Mr. and Mrs. Cromwell and Ruth) returned to Asfar and asked to see pearl inlaid furniture. We took them to the old bazaars and found what they were trying to buy from them. He had asked them fabulous prices. We had asked them to dinner but they refused, but now he turned to Geo and said they would like to have dinner. We at once sent Sammy to start the dinner. It was a hectic afternoon but finally we gained their confidence. Toward evening I bought two bureaus for them for 5.30 pounds and they were delighted. They bought a little statue, door knockers, ivory cat etc. We had a sumptuous dinner lasting from 10 to about 12 midnight sitting on ground around tray.

40 One of Duke's stunning purchases in 1938 was a traditional Damascus painted woodpaneled room that she later modified for one of the rooms in Shangri La. This is the famous traditional 1830 Damascus wood-paneled room. https://www.hisour.com/damascus -room-shangri-la-museum-of-islamic-art-culture-design-49582/. Duke maintained commercial relations with Asfar and Sarkis in the years following her 1938 visit. Doris Duke Papers, Doris Duke Charitable Foundation Historical Archives, David M. Rubenstein Rare Book \& Manuscript Library, Duke University. 


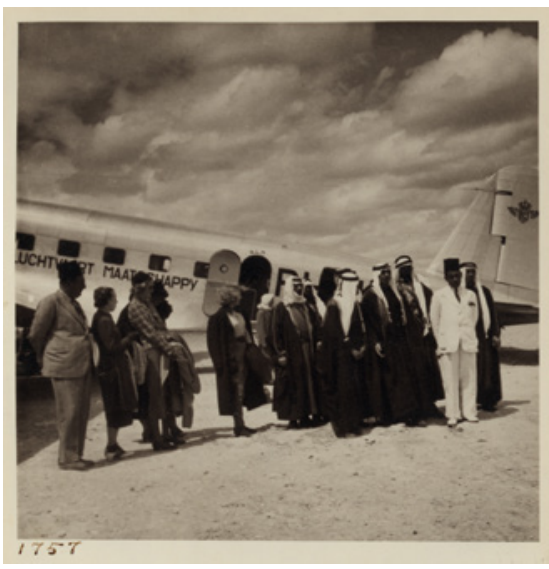

a

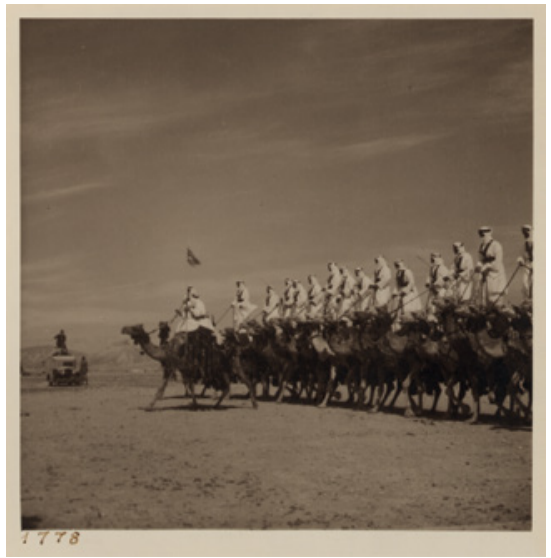

b

FIGURE 7.14

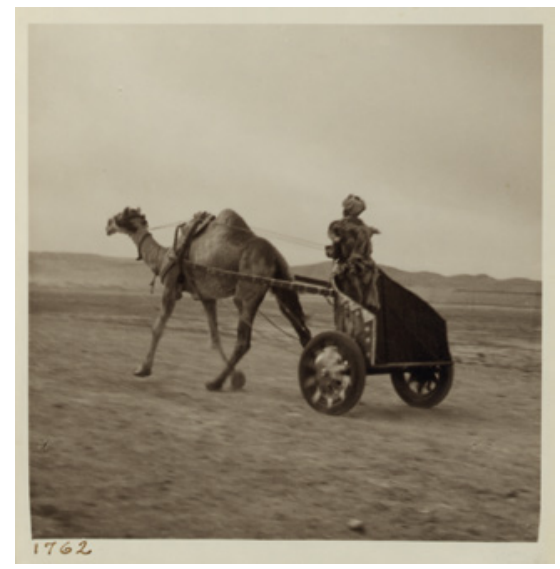

c

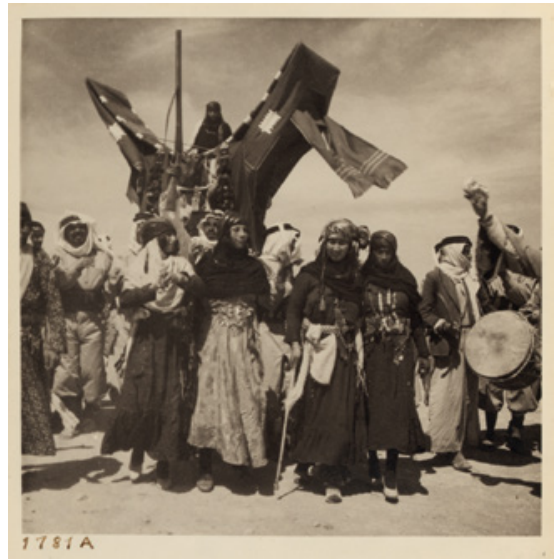

d

To Palmyra with Cromwell Party, April 15-19, 1938

a. Reception party at Palmyra aerodrome, 1938.

b. Desert Patrol riding standing atop camels, 1938 .

c. The camel chariot race driven by black riders in gazell[e]-skin suits, 1938 . d. A Bedouin wedding staged by Gypsies. Accompanying the bride on the mahmal, 1938 .

From John D. Whiting, Diary in Photos, Volume III, 1938. Photograph album. Visual Materials from the Papers of John D. Whiting PRINTS AND PHOTOGRAPHS DIVISION LIBRARY OF CONGRESS, WASHINGTON, D.C. 
At 11:30 a.m. we were in the air. We flew over Damascus and the mosque, and then through the desert to Palmyra. [...] The gardens of Damascus a mosaic, saw the lake for the first time, then the endless, rolling desert. [... We flew] parallel to it, and then to south of Tombs valley. Circled Arab castle and landed at 12:30. Emir Fawaz met us with three negro slaves dressed in purple. We drove to the mayor's home for lunch [...] After lunch - donkey, camel and chariot races. The women could not leave the tents and were sent to the hotel. After supper of roast lamb in open, went to Captain's attractive home, Gypsy dance. ${ }^{41}$ April 18, 1938.

The photographs of the impressive Desert Patrol who ride camels while standing, dressed in long white robes and 'abāya, displays the power of the Palmyra Bedouin community. The photograph of women and children of the city of Palmyra who watched the special demonstration is no less impressive. ${ }^{42}$

A month earlier, Whiting noted in his dairy that while in Damascus to meet the Cromwells, Amīr Fahāmī called and informed him 'that there was to be a big festivity in the desert of Palmyra on the 16, 17, 18 [of April.] We are expecting the Cromwells back on the 15th [of April, writes Whiting] so that will just fit in with our desire to give them a special good time.43

Throughout her lifetime, Doris Duke Cromwell collected over 4,500 items of Islamic art, and eventually established an institution for the preservation of Islamic art that is still active today. ${ }^{44}$ Her home in Hawaii today is the Shangri La Museum for Islamic Art, Design \& Culture.

Asfār and Sārkīs are not identified in the photographic series, but based on the detailed descriptions in Whiting's written diaries, and on photographs taken by Duke, we can imagine their Damascus shop and the elite group of expert dealers that marketed art and antiquities as well as their marketing strategies. Asfār's business acumen and the commercial relations between him and Whiting, on behalf of the American Colony Stores, is apparent but also unexpected. While Whiting waited for Asfār in vain in his store to join in the

41 John D. Whiting, Diaries, John D. Whiting Papers, Manuscript Division, Library of Congress, Washington D.C., Box 3, 1938-1941.

42 John D. Whiting, Diary in Photos, Vol. III, 1938, "To Palmyra with Cromwell party," 15-19 April 1938; "City women watching the races," LC-DIG-ppmsca-17414-ooo88 (Digital file from original on page 48, no. 1769). https://www.loc.gov/resource/ppmsca.17414/?sp=88.

43 John D. Whiting, Diaries, John D. Whiting Papers, Manuscript Division, Library of Congress, Washington D.C., Box 3, 1938-1941.

44 The Shangri La Museum for Islamic Art and Design website displays Islamic Art that was purchased by Doris Duke in Damascus in 1938, as well as the invoices of purchases. https://collection.shangrilahawaii.org/collections/32672/artwork-on-view/objects. 


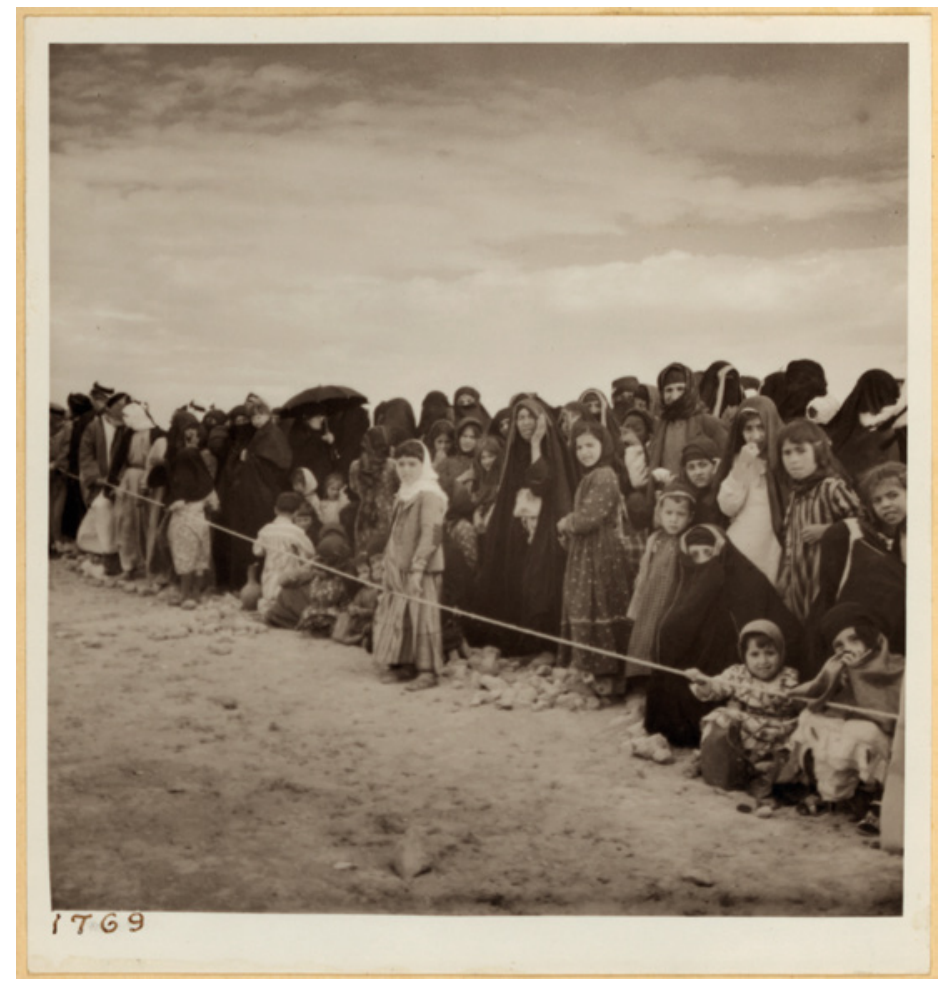

FIGURE 7.15 City Women [and Children] Watching the Races. To Palmyra with Cromwell Party, April 15-19, 1938. From John D. Whiting, Diary in Photos, Volume III, 1938. Photograph album. Visual Materials from the Papers of John D. Whiting PRINTS AND PHOTOGRAPHS DIVISION, LIBRARY OF CONGRESS, WASHINGTON, D.C.

sale of a rug he brought over from Jerusalem, Asfār visited Mrs. Cromwell in her hotel room and sold her the rug for $\$ 39$,ooo.

In his written diary, Whiting describes the fascinating negotiations during which Mrs Cromwell purchased the artifacts from Asfār and Sārkīs and other Damascene merchants and bazaars. The purchase processes included generous hosting in the home of Asfār's partner, Sārkīs, who prepared a feast for lunch: baklawa with meat, stuffed chicken and pastries filled with cream and pistachios. An evening dinner was 'sumptuous', with both hosts and their guests sitting for hours around a tray. ${ }^{45}$

The Diary in Photos series constitutes a selection of approximately 9oo photographs from approximately 2,80o photographs taken by Whiting from 1934 and 1949. It is unfortunate that the rejected images are not available for research online. 
From the moment the group boarded the plane in Palmyra, Whiting documented the series of outdoor events. ${ }^{46}$ In his lens, he captured city women and children watching the races, and the camel chariot race driven by a black man wearing gazelle-skin costumes. He documented the Bedouin camel riders waiting for the signal to mount their saddles and the Desert Patrol in their white uniforms, riding on camels while standing and holding the reigns. The ostentatious display continued with Palmyra 'Gypsies' staging a wedding. First, the bride was raised onto her mahmal tent on camelback accompanied by dancing. The bride was then 'kidnapped' in a staged raid. The 'kidnappers' were caught and the bride was returned to the tent by the Desert Patrol, to the accompaniment of drums and revelry. At the end of the demonstration, a French general awarded prizes to the participants. The particularities of such staged 'kidnapping' on the one hand plays into Orientalist tropes, but in reading the performativity of such an event, and Whiting's diary notes taken in Palmyra, as well as viewing a short home movie taken by the Cromwells ${ }^{47}$ we begin to understand the cultural meaning that underlines the ceremony.

Whiting writes that the event was 'a mock GHAZU,' (a staged ghazū, $)^{48}$ a performative raid that developed from pre-Islamic tribal traditions where tribesmen raided caravans, looted, kidnapped and engaged in slave trade, except during two months of the year that were known as the 'Forbidden Months' or the 'Holy Months.' During these months, the tribes could not launch raids 'for safety of the travellers and trade and survival of the Arab desert's economy.'49

46 John D. Whiting, Diaries, John D. Whiting Papers, Manuscript Division, Library of Congress, Washington D.C., Box 3, 1938-1941.

47 Follow link to the rare footage titled 'Travels in the Middle East 1938' at the Doris Duke Charitable Foundation Historical Archives, David M. Rubenstein Rare Book and Manuscript Library, Duke University. (Minute 17.06 to minute 18.15). https://exhibits. library.duke.edu/exhibits/show/dorisduke/movie.

48 John D. Whiting, Diaries, John D. Whiting Papers, Manuscript Division, Library of Congress, Washington D.C., Box 3, 1938-1941.

Diary notes were taken during 'a mock GHAZU,' e.g., staged launched (GHAZU) raids. The staged GHAZU continued all night with constructing the bridal tent [mahmal,] dancing 'Gypsies' accompanying the bride and depositing her on the tent:

[...] During the joyful event, 'regular bedu' came rushing on their camels firing their rifles and stole the bride, loading her on a camel behind an Arab. The tent [mahmal] was pulled down and dust thrown in the air. The camel corps now arrived from a distance and rescued the bride and brought her back, with the raiders handcuffed.

49 Frederic P. Issace. 2003. "Indigenous People Under the Rule of Islam. Part II: The Rise and Spread of the Message (Ghazu) raid". http://members.oktiv.net/fpi/IPUROI/ 16PART2Ghazzu\%2oRaid.html. 


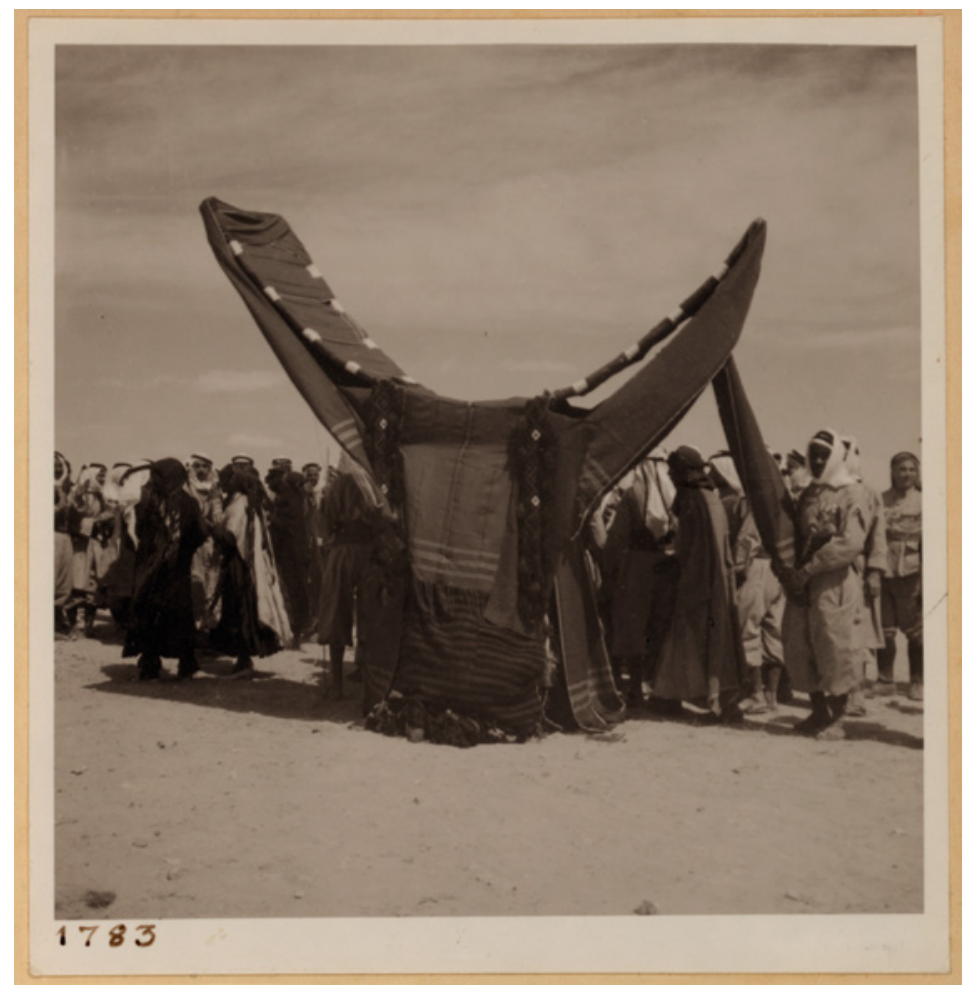

FIGURE 7.16 To Palmyra with Cromwell party, April 15-19, 1938. A traditional 'mock (ghazū)' raid. The bride alights from the camel, 1938.

From John D. Whiting, Diary in Photos, Volume III, 1938.

Photograph album. Visual Materials from the Papers of John D. Whiting

PRINTS AND PHOTOGRAPHS DIVISION, LIBRARY OF CONGRESS, WASHINGTON, D.C.

The performativity of the Bedouins and 'Gypsies', entertainment being one of the predominant industries of the Domari, in the presence of local and international dignitaries shows that the ceremony was likely practised with regularity to memorialise the importance of safe desert commerce, an event that gestures toward a local understanding of cultural diplomacy with the extension of an invitation to the Cromwells during their purchasing expedition.

The setting shows once again the complex space which Whiting inhabited. Given his expert role, facilitating the purchase of artifacts for the Cromwell collection, and his initiative to invite the Cromwells to watch the performance, shows that Whiting understood the Western market for the Orient, in both cultural and mercantile terms. He was also in a position to facilitate 
this within local social networks including the Damascene merchants, the 'regular' Bedouins of Palmyra, the 'Gypsies', the Camel Corps Bedouins and the French regime.

With this in mind, we must place Whiting as a conduit within a broader nexus of modern relations. He was involved in both international and regional networks of art and antiquities sales as well as diplomatic relations. He was also active in regional and local networks of cultural exploration, while facilitating the meeting of meaning-making between cultural consumers and producers, outlined in the introduction to this volume, within a global context. The meeting of the local, the regional and the global as exemplified by the Cromwell's visit shows a complex confluence of actors that range from Amīr Fahāmī, the urban firm of Asfār \& Sārkīs, The American Colony Stores, Whiting himself included; to scholarly international networks, such as Upham Pope; and the Bedouin and Domari performers, whose indigenous knowledge and traditions highlight at least some agency with the proffering of performative cultural production; and, of course, to the Cromwells, whose consumption of culture was shaped by local and global forces. Notwithstanding the power dynamics Whiting shows us - the Bedouin and Domari performers, for instance, are not named in his diary, unlike Western and urban Middle Eastern actors - implicit in this complicated network of actors is the underscoring of local and regional urban-rural divides. This also highlights the importance of contextualising period value as outlined in the previous section.

We might also view the articles Whiting published abroad, both for National Geographic in the US, his consular reports and publications in Sweden, as well as his commercial relations with international clientele as a co-manager of Vester \& Co., American Colony Stores as continuities of his specific understanding of the market for Palestine abroad and the facilitations of local relationships with the west.

The presence of the British Mandate government and increasing tensions between Zionists and Palestinians permeate the photographic diaries, and we may easily apply imperialistic paradigms to the selected examples. Yet analysis of the series shows at the same time an unusual panorama of local cultural and natural phenomenon that is permeated by extensive regional systems of mutual cultural influences. For example, Doris Duke Cromwell's search for Islamic art in the region unfolds patterns of commercial relationships that stretch beyond the Syrian merchants to regional and international networks of dealers and consultants, while local communities joined forces to secure the deal.

Doris Duke Cromwell's fascinating story of her early Islamic art purchasing tour is inspiring, but at the same time it challenges the ethics involved in 
transferring art objects from their places of origin to Western countries, using an extensive local and international commercial network to support the deals and acquisition of cultural artifacts. The UNesco Convention Concerning the Protection of the World Cultural and Natural Heritage ${ }^{50}$ aims to preserve cultural treasures in their places of origin. With the perspective of time, specifically in the light of today's destruction of cultural heritage treasures in Palmyra and Syria, Doris Duke Cromwell's shopping trip for local Islamic art and Duke's efforts to preserve Islamic culture may be judged differently. ${ }^{51}$

By recording his trips, and through a careful editorial process, Whiting managed to create an inter-related personal, cultural, and spatial matrix in time. Studying a visual diary is very different experience to examining topical photograph albums which, according to Nancy Micklewright, ${ }^{52}$ involves viewing a collection of photographs 'that was mediated by some kind of a selection process. Thus, examining a compilation from the point of view of its assembly is a crucial aspect of working with a photographic series. The visual diary presents us with additional challenges. It appears to be a compilation that was arranged chronologically, yet it preserves encoded data that can only be traced through visually migrating back and forth from the detail to the entire corpus.

Modern commentators face additional moral questions. Many historical remnants were lost, including those of the members of the photography collective who left the Colony in the early 1930 s and settled elsewhere in Jerusalem. The large collection of photographs and negatives belonging to Lewis (Hol Lars) Larsson, the chief photographer of the ACPD, disappeared in 1947 from his home on Jerusalem's Nablus Road after it was bombed. A collection of seven thousand negatives belonging to brothers Jamāl and Najīb Albīnā, who joined the ACPD after World War I and pursued their own work later on, also disappeared from storage in the corner of Julian's Way and Mamilla Road in

50 The Unesco Convention for Preservation of Cultural Heritage https://whc.unesco.org/en/ conventiontext/ displays the full convention in several languages.

51 Doris Duke Papers, Doris Duke Charitable Foundation Historical Archives, David M. Rubenstein Rare Book and Manuscript Library, Duke University.

52 Nancy Micklewright, "Alternative Histories of Photography in the Ottoman Middle East," in Photography's Orientalism: New Essays in Colonial Representation, eds. Ali Behdad and Luke Gartlan (Los Angeles: Getty Research Institute, 2013), 75-92. 
Jerusalem after they were forced to leave. ${ }^{53}$ Significant section of photographic collections created by the renowned Palestinian photographer Khalil Ra'ad as well as the work of Ḥannā Ṣāfiyya were also lost.

Local researchers Mustafa Kabha and Guy Raz, ${ }^{54}$ Rona Sela, ${ }^{55}$ and Gish Amit ${ }^{56}$ expose parallel creative processes that have served the ideological policies of nascent Zionism. In expression of that policy, access to photographic remains that were confiscated or appropriated has been blocked for many years, due to the fear that the data they contained would be used to contradict the dominant ideology.

In contrast, pre-1948 Christian research institutions in Palestine preserve large bodies of unprocessed photographic oeuvre as can be seen in the work of Karène Sanchez Summerer and Norig Neveu in this volume. The slow exposure of these materials presents us with additional challenge. While political conflicts present a physical threat to photography, an ideological threat is rooted in the interpretability of photographic remnants that were preserved and are accessible to us, such as Whiting's Diaries in Photos or the photograph collection of the École Biblique, in a manner that will enable us to extract the 'parallel alternative histories' trapped within the genres. ${ }^{57}$

Travel and exploration reflect continuous relationships between the photographer and the subject, and the photographer and the landscape. Through exploration of these relationships a complex visual historiographic record is written. In the manner that it is edited, a thematic photographic album often erases parts of history and reorganises other parts. According to David Bate, this editing process represents an ideological apparatus through which the editor reprograms existing memory, not in the way it was, but in the way he wishes others to remember it. ${ }^{58}$ In essence, Bate claims, this is an iconoclastic argument, because the range of images in an album differ from those recorded in the human memory. Similarly, Bate also asserts that the growth of museums and cultural institutions envelops within it the trend of redesigning

53 Iris Albina, "Souvenir from Gethsemane: Portrait of the Albina Brothers," Jerusalem Quarterly 6o (2014): 59 .

54 Mustafa Kahba and Guy Raz, Memory of Place: A Photographic History of Wadi Ara, 19032008 (Jerusalem: The Umm El-Fahem Art Gallery, 2008).

55 Rona Sela, For Public Review: Photographs of Palestinians in Military Archives in Israel (Tel Aviv: Helena Publishing, 2009).

56 Amit Gish, Ex Libris: The History of Appropriation, Preservation, and Theft in the National Library of Jerusalem (Jerusalem: Van Leer Institute, 2014).

57 See Karène Sanchez Summerer and Norig Neveu's chapter in this volume, "The Dominicans Photographic Collection in Jerusalem."

58 David Bate, "The Memory of Photography," Photographies 3, no. 2 (September 2010): 25 o. 
human memory by erasing elements that were rejected from the cultural sphere by institutions of the dominant regime. Bate ${ }^{59}$ refers also to Foucault's iconoclastic argument in 'Film and Popular Memory'60 and compares a photographic corpus to 'image banks' that can potentially suppress personal memory and often replaces it.

Exploring the Diary in Photos reveals an unfamiliar reality that escaped the editing process - a Middle East that is unfettered by borders and populated by permanent and changing, mutually influential heterogeneous groups, as well as dominating foreign political forces. The historical memory of the Zionist-Palestinian conflict is present in Whiting's work, but it does not become dominant, due to the swift transitions which are the inherent nature of the genre. Examining Whiting work solely through the Orientalist paradigms ignores the richness of its cultural diversity and the memory of an open-borders Middle East.

The Diary in Photos series maintains a rather fluid 'meta-form' that absorbed complex visual memories through the day-by-day visual documentation. It resembles therefore a motion picture: its singular frames cannot exist without relating them to the sequence. Modern interpretation must therefore decipher it and release the broad range of 'parallel alternative histories' trapped in its entirety. An index of Whiting's 1934 and 1935 trips emphasises the cultural jigsaw captured in the entire work. ${ }^{61}$ The genre's perspective fits well within the photographic work created by other Christian explorers in Jerusalem, but remained unexplored for generations. It was created as Whiting's personal memory apparatus, but at the same time it maintains a matrix of popular cultural memory 'which existed but had no way for expressing itself', ${ }^{62}$

We must aim to develop reflective, critical visual tools that will enable us release the 'meta forms' that are trapped in confined bodies of work, rather than extracting components in an attempt to justify dominant ideologies or Orientalist paradigms. This will enable a new reading, and even if such readings are only partial, they have the power to gradually create a 'meta-archive' that can potentially inspire a sense of belonging and identity of younger generations in the region.

\footnotetext{
59 Ibid., 251.

6o Michel Foucault, "Film and Popular Memory," Reprinted in Foucault Live (New York: Semiotexte, 1989).

61 Rachel Lev, Index of photographic series presented in Diary in Photos vol. I, 1934-1935, Parts I and II. (September 2020) https://drive.google.com/drive/folders/19IYnTPU-6Fih KtJfwpo8Kgh ${ }_{5} \mathrm{CfM}_{7} \mathrm{qKzU}$ ? usp=sharing. 


\section{Bibliography}

\section{Archival Sources}

A John D. Whiting, Diaries in Photos

Whiting, John D. Diary in Photos vol. I, 1934-1935. Visual materials from the papers of John D. Whiting. Library of Congress, Washington D.C. https://www.loc.gov/ item/2007675295/.

Whiting, John D. Diary in Photos vol. II, 1936-1937. Visual materials from the papers of John D. Whiting. Library of Congress, Washington D.C. https://www.loc.gov/ item/2007675297/.

Whiting, John D. Diary in Photos vol. III, 1938. Visual materials from the papers of John D. Whiting Library of Congress, Washington D.C. https://www.loc.gov/ item/2007675285/.

Whiting, John D. Diary in Photos vol. IV, 1938. Visual materials from the papers of John D. Whiting. Library of Congress, Washington D.C. https://www.loc.gov/ item/2007675264/.

Whiting, John D. Diary in Photos vol. v, 1939. Visual materials from the papers of John D. Whiting. Library of Congress, Washington, D.C. https://www.loc.gov/ item/200767529o/.

B John D. Whiting, Written Diaries

Whiting, John D. Diaries. John D. Whiting Papers. Manuscript Division, Library of Congress, Washington D.C. Box 1, 1905-1918; Box 2, 1934-1935; Box 3, 1938-1941. (Typed transcript of John D. Whiting Diaries. American Colony Archive Collections, Jerusalem. Restricted Access.).

C John D. Whiting, Consular Reports

Whiting, John D. Consular Reports, 1909-1915. John D. Whiting Papers. Manuscript Division, Library of Congress, Washington D.C., Box 16, 1909-1915.

D John D. Whiting, National Geographic Articles, 1913-1940

Library of Congress, Washington, D.C. LC Call number: G1.N27.

Copies of NGM issues with Whiting articles are also found in the Manuscript Division John D. Whiting Papers along with correspondence related to the articles.

Whiting, John D. "From Jerusalem to Aleppo." National Geographic Magazine xxIV (January 1913): 71-113.

Whiting, John D. “Jerusalem's Locust Plague." National Geographic Magazine XXVIII (December 1915): 511-550.

Whiting, John D. "The Last Israelitish [Israelite] Blood Sacrifice: How the Vanishing Samaritans Celebrate the Passover on Sacred Mount Gerizim." National Geographic 
Magazine XXXVII (January 1920): 1-46. https://archive.org/details/lastisraelitish boowhit/page/42/mode/2up.

Whiting, John D. "Among the Bethlehem Shepherds: A Visit to the Valley Which David Probably Recalled When He Wrote the Twenty -third Psalm." National Geographic Magazine L (December 1926): 729-753.

Whiting, John D. "Bethlehem and the Christmas Story." National Geographic Magazine LVI (December 1929): 699-736.

Whiting, John D. “Petra, Ancient Caravan Stronghold.” National Geographic Magazine LXVII (February 1935): 129-165.

Whiting, John D. "Bedouin Life in Bible Lands. the Nomads of the 'House of Hair' Offer Unstinted Hospitality to an American." National Geographic Magazine LXXI (January 1937): $5^{8-83}$.

Whiting, John D. "Where Early Christians Lived in Cones of Rock: A Journey in Cappadocia in Turkey." National Geographic Magazine LXXVI, no. 6 (December 1939): 763-802.

Whiting, John D. "Canoeing down the River Jordan." National Geographic Magazine LXXVIII (December 1940): 781-8o8.

\section{Secondary Sources}

Ariel, Yaakov and Ruth Kark. "Messianism, Holiness, Charisma, and Community: The American-Swedish Colony in Jerusalem, 1881-1933." Church History 65, no. 4 (1996): 641-657.

Barthes, Roland. Camera Lucida. New York: Hill and Wang, 1981.

Bate, David. "The Memory of Photography." Photographies 3, no. 2 (2010): 243-257.

El-Hajj, Badr. "Khalil Raad, Jerusalem Photographer." Journal of Palestine Studies 11-12 (2001): 34-39.

Foucault, Michel. "Film and Popular Memory." Reprinted in Foucault Live. New York: Semiotext(e), 1989 .

Freud, Sigmund. "The 'Mystic Writing-pad'” Reprinted in On Metapsychology: The Theory of Psychoanalysis: Beyond the Pleasure Principle, Ego and the Id and Other Works, edited by Albert Dickson, 427-433. Harmondsworth: Penguin, 1984.

Gish, Amit. Eks libris: historyah shel gezel, shimur ye-nikus ba-Sifriyah ha-le'umit bi-Yerushalayim (Ex Libris: The History of Appropriation, Preservation, and Theft in the National Library of Jerusalem). Jerusalem: Van Leer Institute, 2014.

Hackforth-Jones, Jocelyn and Mary Roberts. "Introduction: Visualising Culture across the Edges of Empires." In Edges of Empire: Orientalism and Visual Culture, edited by Jocelyn Hackforth-Jones and Mary Roberts, 1-19. Oxford: Blackwell Publishing, 2005 .

Kabha, Mustafa and Guy Raz. Memory of Place: A Photographic History of Wadi Ara, 1903-2008. Jerusalem: The Umm el-Fahem Art Gallery, 2008. 
Kracauer, Siegfried. History: The Last Things before the Last. Translated by Paul Oskar Kristellar. Princeton: Wiener, 1994.

Le Goff, Jacques. History and Memory. Translated by Steven Rendall and Elizabeth Claman. New York: Columbia University Press, 1992.

Lind, E. Lars. "Jerusalem Before Zionism and the American (Swedish) Colony." Lars E. Lind Papers. Box 2. Manuscript Division, Library of Congress, Washington D.C. (1979).

Micklewright, Nancy. "Alternative Histories of Photography in the Ottoman Middle East." In Photography's Orientalism: New Essays in Colonial Representation, edited by Ali Behdad and Luke Gartlan, 75-92. Los Angeles: Getty Research Institute, 2013. Mickelwright, Nancy. "Orientalism and Photography." In The Poetics and Politics of Place: Ottoman Istanbul and British Orientalism, edited by Zeynep Inankur, Reina Lewis and Mary Roberts, 99-110. Seattle, WA: University of Washington Press, 2011.

Micklewright, Nancy. "Personal, Public, and Political (Re) Constructions: Photographs and Consumption." In Consumption Studies and the History of the Ottoman Empire, edited by Donald Quataert, 261-86. Binghamton: sunY Press, 2000.

Nassar, Issam. "The Wasif Jawharieh Photographic Collection." Journal of Palestine Studies 11-12 (2001): 39-43.

Nir, Yeshayahu. The Bible and the Image: The History of Photography in the Holy Land 1839-1899. Philadelphia: University of Pennsylvania Press, 1986.

Onne, Eyal. The Photographic Heritage of the Holy Land, 1839-1914. Manchester: Manchester Polytechnic, 1980.

Raz, Guy. "Fifty years to Helmar Lerski's Death: A Pioneer of Modern Photography in Palestine," (In Hebrew) Haaretz, September 27, 2006. http://www.haaretz.co.il/ literature/1.1140718.

Raz, Guy. "The Photographer is the Mirror-Image of His Landscape." (In Hebrew) Avi Chai website (2011). http://www.bac.org.il/hbrha/article/hatzlm-hava-tbnyt -nvph-mvldtv.

Said, Edward. Orientalism. New York: Vintage Books, 1979.

Sela, Rona. In the Eyes of the Beholder - Aspects of Early Palestinian Photography. Translated from the Hebrew under the title Photography in Palestine/The Land of Israel in the 1930s-40s. Herzlia: Hakibbutz Hameu'had and Herzliya Museum of Art, 2000.

Sela, Rona. Photography in Palestine/The Land of Israel in the 1930s-40s. (In Hebrew) Hertzlia: Hakibbutz Hameu'had and Herzliya Museum of Art, 200o. http://www .ronasela.com/he/details.asp?listid=39.

Sela, Rona. "For Public Review: Photographs of Palestinians in Military Archives in Israel." (In Hebrew) Tel Aviv: Helena Publishing, 2009.

Sela, Rona. "Land of Mirrors." (In Hebrew) Haaretz, July 22, 2011. http://www.haaretz. co.il/misc/1.1181774. 
Sela, Rona. Halil Ra'ad: tatslumim 1891-1948. Tel Aviv: Helena Publishing, 2013.

Tveit, Odd Karsten. Anna's House, the American Colony in Jerusalem. Translated by Peter Scott-Hansen. Nicosia: Rimal Publication, 2011.

Wasserstein, Bernard. "Clipping the Claws of Colonisers': Arab Officials in the Government of Palestine, 1917-1948." Middle Eastern Studies 13, no 2 (1977): 171-194. Whiting, John D. and Lewis Larsson. Samaritanernas päskfest I ord och bild. (Passover Celebrations of the Samaritans in Words and Pictures). With introductions by Sven Anders Hedin and Selma Lagerlöf. Limited edition, no. 159 of 30o. Stockholm: Albert Bonniers Forlag. Rare Books Collection, American Colony Archive, Jerusalem, 1917. Woodward, Michelle L. "Between Orientalist Clichés and Images of Modernization: Photographic Practice in the Late Ottoman Era." History of Photography 27, no. 4 (2003): 363-74.

Woodward, Michelle L. "Creating Memory and History." Photographies 2, no. 1 (2009): 21-35. 